\title{
‡USGS

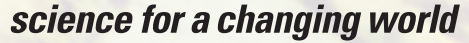

Metallogeny of Mesoproterozoic Sedimentary Rocks in Idaho and Montana - Studies by the Mineral Resources Program, U.S. Geological Survey, 2004-2007

Open-File Report 2007-1280

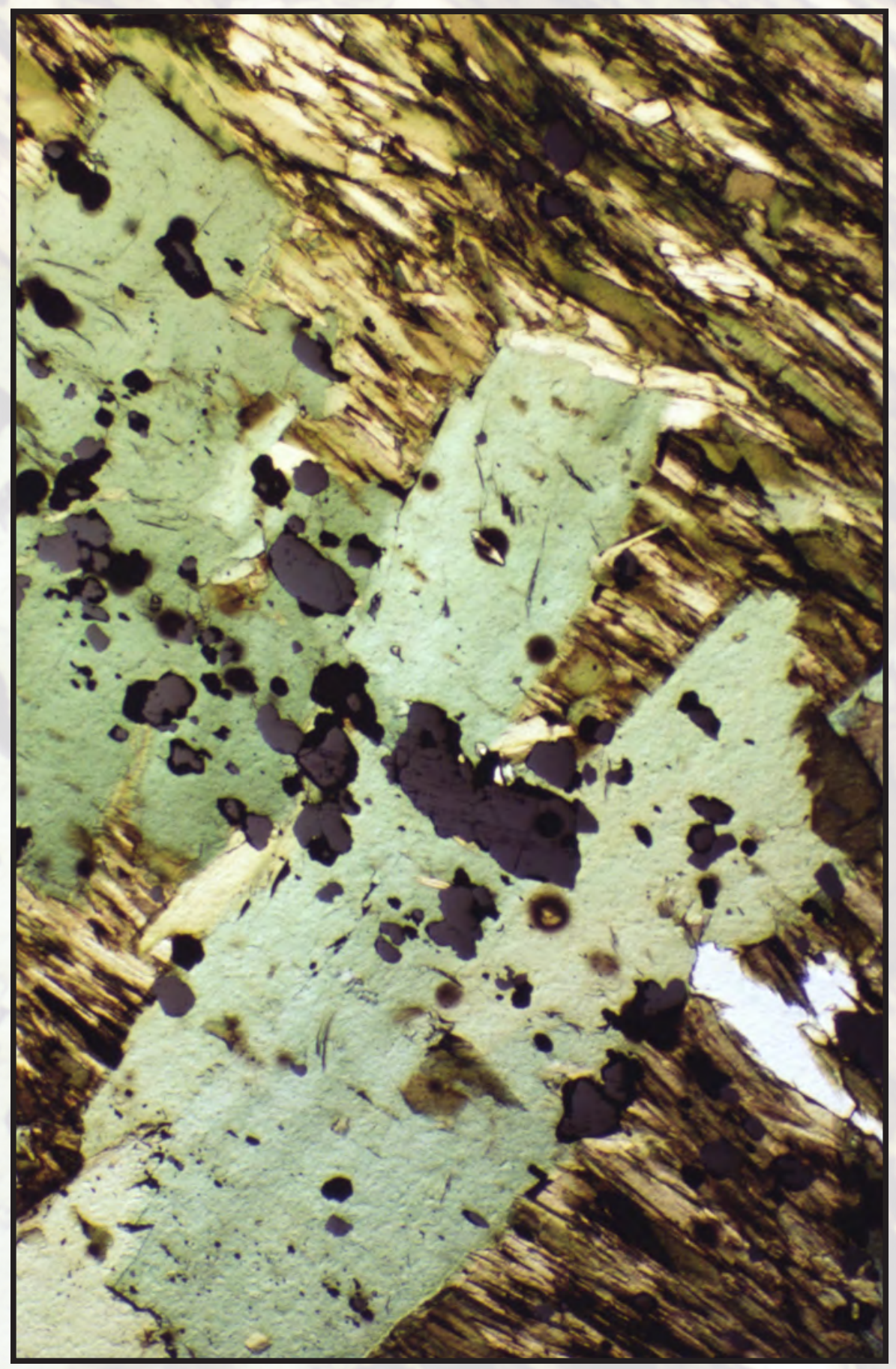

U.S. Department of the Interior U.S. Geological Survey 


\section{Metallogeny of Mesoproterozoic Sedimentary Rocks in Idaho and Montana-Studies by the Mineral Resources Program, U.S. Geological Survey, 2004-2007}

Edited by J. Michael O'Neill

Contributions by J. Michael O'Neill, Edward T. Ruppel, David A. Lopez, Arthur A. Bookstrom, Craig A. Johnson, Gary P. Landis, Thomas P. Frost, and John F. Slack

Volume comprises Chapters A, B, and C

Open-File Report 2007-1280 


\section{U.S. Department of the Interior DIRK KEMPTHORNE, Secretary}

\section{U.S. Geological Survey \\ Mark D. Myers, Director}

\section{U.S. Geological Survey, Reston, Virginia: 2007}

For sale by U.S. Geological Survey Information Services

Box 25286, Denver Federal Center

Denver, CO 80225

For more information on the USGS — the Federal source for science about the Earth, its natural and living resources, natural hazards, and the environment:

World Wide Web: http://www.usgs.gov

Telephone: 1-888-ASK-USGS

Any use of trade, product, or firm names is for descriptive purposes only and does not imply endorsement by the U.S. Government.

This publication has not been reviewed for stratigraphic nomenclature.

Although this report is in the public domain, permission must be secured from the individual copyright owners to reproduce any copyrighted materials contained within this report.

Suggested citation:

O'Neill, J.M., ed., 2007, Metallogeny of Mesoproterozoic sedimentary rocks in Idaho and Montana-Studies by the Mineral Resources Program, 2004-2007: U.S. Geological Survey Open-File Report 2007-1280, 28 p.; available at http://pubs.usgs.gov/of/2007/1280

Cover: Photomicrograph of a thin section, showing cobaltite grains (bluish gray) in biotite phyllite (yellowish to brownish green) with chloritoid porphyroblasts (pale green). The sample is from the Blackbird mine area, Lemhi County, Idaho. The thin section was photographed in plane-polarized transmitted light with incident light reflected from opaque cobaltite grains. The image was supplied by Stephen G. Peters, U.S. Geological Survey. 


\section{Volume Contents}

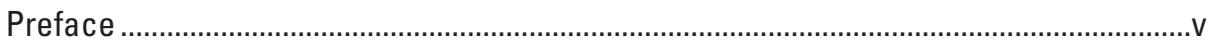

By J. Michael O'Neill

A. Great Divide Megashear, Montana, Idaho, and Washington-An Intraplate Crustal-

Scale Shear Zone Recurrently Active Since the Mesoproterozoic ...................................3

By J. Michael O'Neill, Edward T. Ruppel, and David A. Lopez

B. Blackbird Fe-Cu-Co-Au-REE Deposits.

By Arthur A. Bookstrom, Craig A. Johnson, Gary P. Landis, and Thomas P. Frost

C. Geochemical and Mineralogical Studies of Sulfide and Iron Oxide Deposits in the Idaho Cobalt Belt.

By John F. Slack

\section{Conversion Factors}

\section{Units of measure}

The following table lists conversion factors useful for this report:

\begin{tabular}{lll}
\hline Multiply SI unit & By & To obtain English unit \\
\hline centimeter $(\mathrm{cm})$ & 0.3937 & inch (in.) \\
kilometer $(\mathrm{km})$ & 0.6214 & mile $(\mathrm{mi})$ \\
meter $(\mathrm{m})$ & 3.281 & foot $(\mathrm{ft})$ \\
metric tonne & 1.1025 & English ton \\
\hline
\end{tabular}




\section{Abbreviations Used in This Report}

\begin{tabular}{|c|c|c|c|}
\hline \multicolumn{2}{|r|}{ Unit of measure } & \multicolumn{2}{|r|}{ Initialism } \\
\hline $\mathrm{cm}$ & centimeter, centimeters & HREE & Heavy rare-earth elements \\
\hline \multirow{2}{*}{$\mathrm{Ga}$} & giga-annum, billion years & \multirow{2}{*}{ ICP-MS } & \multirow{2}{*}{$\begin{array}{l}\text { inductively coupled plasma- } \\
\text { mass spectrometry }\end{array}$} \\
\hline & gram, grams & & \\
\hline \multirow{3}{*}{$\begin{array}{l}\mathrm{g} \mathrm{Au} / \mathrm{t} \\
\mathrm{km} \\
\mathrm{kt}\end{array}$} & grams of Au per metric tonne & ICP-OES & $\begin{array}{l}\text { inductively coupled plasma- } \\
\text { optical emission spectrometry }\end{array}$ \\
\hline & kilometer, kilometers & \multirow[b]{2}{*}{ INAA } & \multirow{2}{*}{$\begin{array}{l}\text { instrumental neutron activation } \\
\text { analysis }\end{array}$} \\
\hline & thousand metric tonnes & & \\
\hline $\mathrm{m}$ & meter, meters & IOCG & iron oxide-copper-gold \\
\hline Ma & Mega-annum (millions of years ago) & LREE & Light rare-earth elements \\
\hline Mt & million metric tonnes & \multirow{2}{*}{$\mathrm{pH}$} & \multirow{2}{*}{$\begin{array}{l}\text { potential of hydrogen; a } \\
\text { measure of acidity }\end{array}$} \\
\hline $\mathrm{mi}$ & mile, miles & & \\
\hline m.y. & million years (time interval) & REE & Rare-earth elements \\
\hline $\mathrm{ppb}$ & parts per billion & SEDEX & sedimentary-exhalative \\
\hline ppm & parts per million & \multirow{2}{*}{ SEM } & \multirow{2}{*}{ scanning electron microscope } \\
\hline $\mathrm{t}$ & metric tonne & & \\
\hline \multirow{3}{*}{$\begin{array}{l}\text { vol percent } \\
\text { wt percent }\end{array}$} & \multirow{3}{*}{$\begin{array}{l}\text { volume percent } \\
\text { weight percent }\end{array}$} & SEM-EDS & $\begin{array}{l}\text { scanning electron microscape- } \\
\text { energy dispersive spectrometry }\end{array}$ \\
\hline & & SHRIMP & $\begin{array}{l}\text { sensitive high-resolution ion } \\
\text { microprobe }\end{array}$ \\
\hline & & VMS & volcanogenic massive sulfide \\
\hline
\end{tabular}




\title{
Preface
}

\author{
By J.Michael O'Neill
}

The major emphasis of this project was to extend and refine the known Mesoproterozoic geologic and metallogenic framework of the region along and adjacent to the Idaho-Montana boundary north of the Snake River Plain. The Mesoproterozoic metasedimentary rocks in this part of east-central Idaho host important Cu-Co-Au stratabound mineral resources as well as younger, epigenetic hydrothermal, sulfide base-metal mineral deposits. Two tasks of this study were to more accurately understand and portray the character and origin of cobalt-copper-gold deposits that compose the Idaho cobalt belt and specifically to analyze ore mineralogy and metallogenesis within the Blackbird mining district in the central part of the belt. Inasmuch as the cobalt belt is confined to the Mesoproterozoic Lemhi Group strata of east-central Idaho, geologic investigations were also undertaken to determine the relationship between strata of the Lemhi Group and the more extensive, noncobalt-bearing, Belt-Purcell Supergroup strata to the north and northwest.

Abrupt lateral differences in the character and thickness of stratigraphic units in the Mesoproterozoic Lemhi Basin may indicate differential sedimentation in contemporaneous fault-bounded subbasins. It is suggested that northeast-trending basement faults of the Great Falls tectonic zone controlled development of the subbasins. O'Neill and others (chapter A, this volume) document a second major basement fault in this area, the newly recognized northwest-striking Great Divide megashear, a zone 1-2 km wide of left-lateral strike-slip faults active during Mesoproterozoic sedimentation and bounding the Cu-Co belt on the northwest. The megashear is a crustal-scale tectonic feature that separates Lemhi Group strata from roughly coeval Belt-Purcell strata to the north and northwest in Montana and northern Idaho.

The results of numerous geologic investigations of the $\mathrm{Cu}$ - and Co-bearing Mesoproterozoic rocks of east-central Idaho are integrated and summarized by Bookstrom and others (chapter B, this volume). In particular, their field investigations and analysis of evidence and previous arguments for synsedimentary versus epigenetic mineral deposit types, both of which have been postulated by earlier workers, led them to conclude that both processes were likely instrumental in forming the ore deposits of the Blackbird district.

Finally, this report supplies new data on isotopic ratios of sulfur, oxygen, carbon, and helium in minerals associated with cobalt-bearing ores of the cobalt belt. Slack (chapter C, this volume) identified several previously unrecognized rare-earth-element minerals in Blackbird ores: monazite (Ce,La, Y,Th)PO ${ }_{4}$, xenotime $\left(\mathrm{YPO}_{4}\right)$, allanite $(\mathrm{CaCe})_{2}\left(\mathrm{Al}, \mathrm{Fe}_{3} \mathrm{Si}_{3} \mathrm{O}_{12}(\mathrm{OH})\right.$, and gadolinite $\left(\mathrm{Be}_{2} \mathrm{FeY}_{2} \mathrm{Si}_{2} \mathrm{O}_{10}\right)$. Light rare-earth elements reside mostly in monazite, whereas yttrium and heavy rare-earth minerals reside mostly in xenotime. Dated monazite, which in the Blackbird district is interstitial to cobaltite, is Cretaceous. This date brings into question the otherwise geologically convincing interpretation of Blackbird ores as being of Mesoproterozoic age and synsedimentary origin.

This volume consists of three summary articles:

A. Great Divide megashear, Montana, Idaho, and Washington-An intraplate crustal-scale shear zone recurrently active since the Mesoproterozoic by J. Michael O'Neill, Edward T. Ruppel, and David A. Lopez

B. Blackbird Fe-Cu-Co-Au-REE deposits by Arthur A. Bookstrom, Craig A. Johnson, Gary P. Landis, and Thomas P. Frost

C. Geochemical and mineralogical studies of sulfide and iron oxide deposits in the Idaho cobalt belt by John F. Slack 


\section{Great Divide Megashear, Montana, Idaho, and Washington-An Intraplate Crustal- Scale Shear Zone Recurrently Active Since the Mesoproterozoic}

By J. Michael O'Neill, Edward T. Ruppel, and David A. Lopez

\section{Chapter A of}

Metallogeny of Mesoproterozoic Sedimentary Rocks in Idaho and Montana-Studies by the Mineral Resources Program, U.S. Geological Survey, 2004-2007

Edited by J. Michael O'Neill

Open-File Report 2007-1280-A 


\section{Contents}

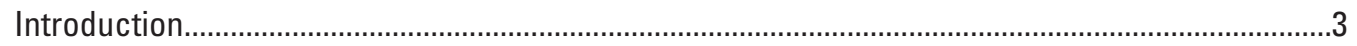

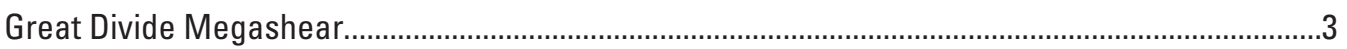

Deadman and Bloody Dick Segments ...............................................................................

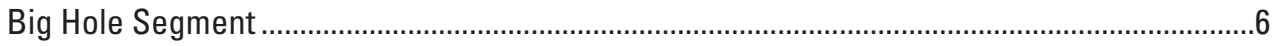

Painted Rocks Segment...................................................................................................

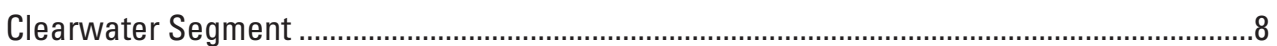

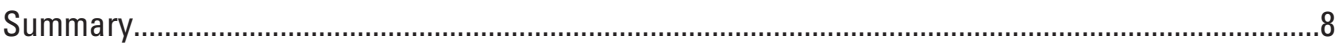

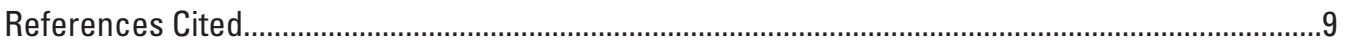

\section{Figures}

1. Index map of northern Rocky Mountains and adjacent area showing the lateral extent of the Great Divide megashear

2. Northwest-trending faults in the northern Rocky Mountains, including the trace of the Great Divide megashear.

3. Northern Rocky Mountains showing location of the Great Falls tectonic zone and the left-lateral offset of the Dillon shear zone by the Great Divide megashear. 


\title{
Great Divide Megashear, Montana, Idaho, and Washington-An Intraplate Crustal-Scale Shear Zone Recurrently Active Since the Mesoproterozoic
}

\author{
By J. Michael O’Neill, Edward T. Ruppel, and David A. Lopez
}

\section{Introduction}

A regional set of northwest-trending faults in southwestern Montana comprises more than 30 major subparallel crustal fractures that have been active since Mesoproterozoic time. Displacements along these faults have differed over time and include left-lateral strike-slip, reverse oblique-slip, and normal displacement. These faults first moved during the formation of the Mesoproterozoic Belt Basin (Winston, 1986; Sims and others, 2004), when left-lateral strike-slip faults caused extension, rifting, and subsidence. Along the southern margin of the basin these faults have been shown locally to have dip-slip displacement and to have controlled sedimentation patterns during deposition; Belt sedimentary rocks, where they cross these faults, display rapid facies and thickness changes (O'Neill and others, 1986; Schmidt and Garihan, 1986; O’Neill, 1995).

Neoproterozoic and early Paleozoic normal displacement along early Belt Basin faults has been demonstrated by Wooden and others (1978), Ruppel (1985), and Harlan and others (1990). Neoproterozoic dikes were intruded along the traces of these faults and provided conduits for syngenetic base metal mineralization in overlying Belt sedimentary rocks (Thorson, 1984). Cambrian rocks in the Tobacco Root Mountains and other mountain ranges in southwest Montana (Ruppel, 1985) display thinning of basal sands and shallowwater reefs on upthrown blocks.

Late Cretaceous Laramide oblique-slip displacement on northwest-trending faults is well documented (Reid, 1957; Foose and others, 1961; Swanson, 1970; Schmidt and Hendrix, 1981; Garihan and others, 1982; Schmidt and O'Neill, 1982; Schmidt and Garihan, 1983; O'Neill and others, 1986; Schmidt and Garihan, 1986). Movement on the northwesttrending faults is responsible for 9-16 miles (15-25 kilometers $(\mathrm{km})$ ) of shortening of the foreland crust of southwest Montana by left-lateral reverse slip (Schmidt and Garihan, 1983).

The most recent movement on northwest-trending faults accommodated late Tertiary and Quaternary faulting and extension in southwestern Montana (Pardee, 1950; Reynolds, 1979; Ruppel, 1982; O’Neill and others, 1986; Schmidt and Dresser, 1986; Stickney and Bartholomew, 1987). Recurrent movement along this older set of northwest-trending faults has controlled the location and orientation of basin and range block faults and has segmented Late Cretaceous overthrust belt structures; present day fault scarps, landslides, and displaced alluvial fans document ongoing movement along the traces of the older faults.

The Great Divide megashear of Montana and Idaho, newly recognized and described here, represents the westernmost fault zone of the regional set of northwest-trending structures in southwest Montana; it is also the most structurally complex. This megashear, unlike similar left-lateral strike-slip faults of the Rocky Mountain foreland to the east, separates two very different geologic terranes. These terranes were brought together by strike-slip faulting, rather than by thrust faulting as interpreted earlier (Skipp and Hait, 1977; Ruppel, 1978; Ruppel and Lopez, 1984).

\section{Great Divide Megashear}

The Great Divide megashear extends northwest from the Snake River Plain into southwest Montana, thence northwestward, east of but parallel to the Continental Divide along the Montana-Idaho state line, across the West Fork of the Bitterroot River, and into adjacent Idaho (figs. 1, 2). Between the Snake River Plain and the Bitterroot River the megashear is a left-lateral strike-slip deformation belt that, at the surface, is characterized by a steeply dipping anastomosing array of faults, commonly with many bends and left-stepping offsets of individual fault strands. The megashear separates geologic terranes that have different and characteristic stratigraphic sequences, geologic structure, topography, and drainage patterns. No formations cross the megashear. Northwest of the Montana-Idaho state boundary, along the Continental Divide, the megashear merges with the Clearwater zone (Sims and others, 2005), interpreted as a deep-seated crustal tectonic zone marked by a strong negative linear aeromagnetic anomaly that can be traced across central Idaho into east-central Washington and whose geophysical signature is similar in size and intensity to that of the Lewis and Clark line in west-central Montana. Total length of the combined megashear exceeds $500 \mathrm{~km}$. 


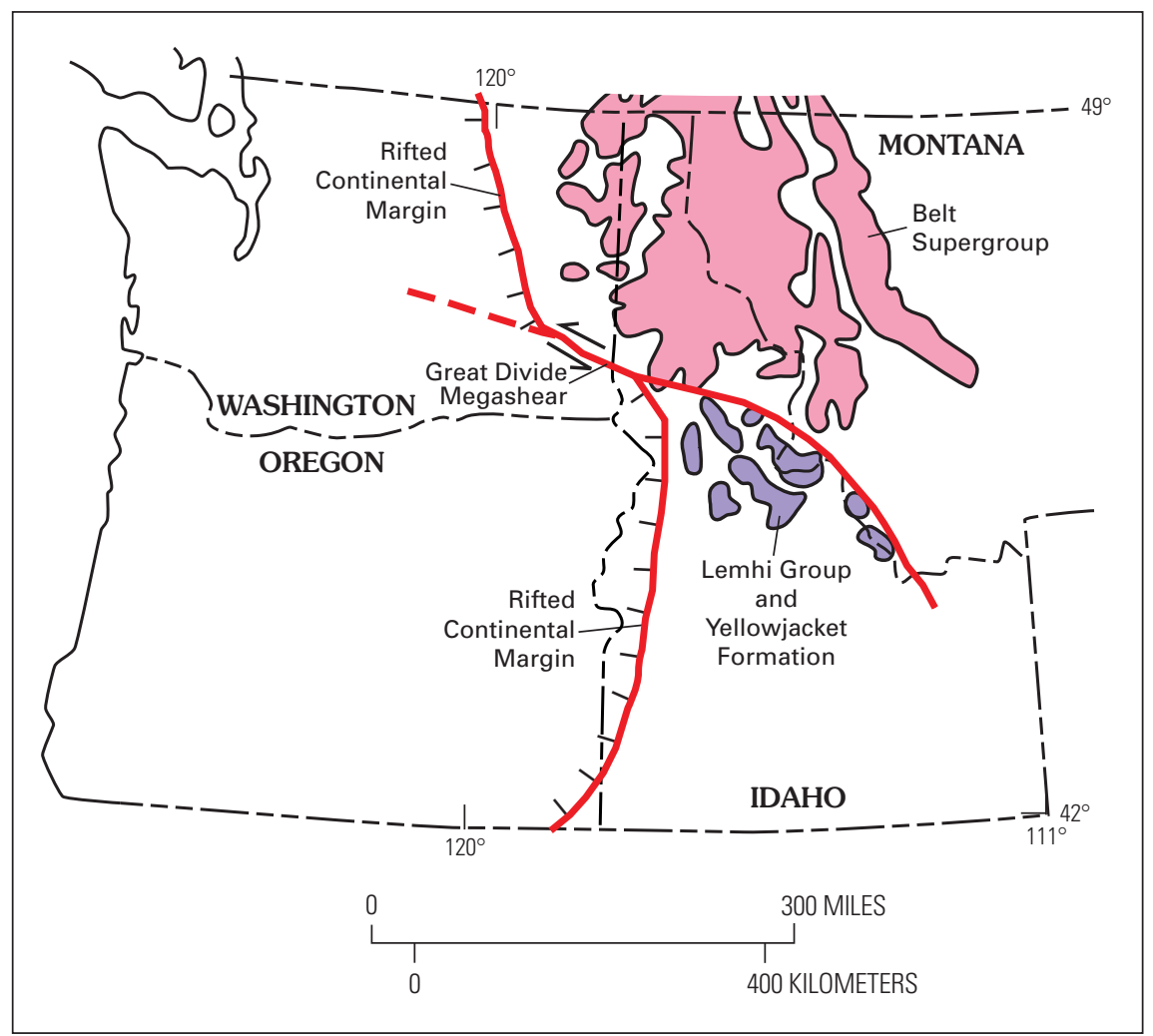

Figure 1. Index map of northern Rocky Mountains and adjacent area showing the lateral extent of the Great Divide megashear. The megashear extends northwesterly from the Snake River Plain, parallel to the Idaho-Montana state line, gently curves west-northwest across central Idaho, and continues into eastern Washington, where it follows the trace of the Trans-Idaho discontinuity (modified from Burchfiel and others, 1992). Rock units in colored areas discussed in text.

In extreme southwest Montana and adjacent Idaho the megashear is divided into four interconnected segments, two of which are left stepping (fig. 2). The Deadman and Bloody Dick segments are well exposed and include some individual faults that have been mapped previously. The Big Hole segment is concealed beneath Tertiary sediments in the Big Hole Basin; and the Painted Rocks segment, although well exposed, has not been recognized until now. The Clearwater segment has been recognized only as a through-going aeromagnetic negative anomaly (Sims and others, 2005).

\section{Deadman and Bloody Dick Segments}

The southernmost part of the megashear, the Deadman segment, incorporates some faults mapped by others along its trace, including the original Deadman fault of Scholten and others (1955), in a complex of steeply dipping, interlacing strike-slip faults. The Deadman segment trends northwest from the Snake River Plain for more than $60 \mathrm{~km}$ (fig. 2 map) and is a zone of interlacing faults, in places as much as $8 \mathrm{~km}$ wide.

The Deadman zone everywhere separates rocks and rock sequences of central Idaho from those of southwest Montana.
West of the Deadman zone, the sequence of sedimentary rocks is dominated by thick quartzites and siltites of the Mesoproterozoic Lemhi Group and the Swauger Formation. Above the Mesoproterozoic rocks of east-central Idaho, and typically faulted against them, are basal Paleozoic formations of the Ordovician Summerhouse Formation, the massive white quartzite of the Kinnikinic Quartzite, and the dark dolomite of the Saturday Mountain Formation.

In southwest Montana Mesoproterozoic sedimentary rocks are absent northeast of the Deadman zone in the Tendoy Mountains. The basal Paleozoic rocks above the basement crystalline rocks of the Archean Wyoming Province are Cambrian Flathead Sandstone and overlying Cambrian, Devonian, and younger Paleozoic formations not found southwest of the Deadman segment.

The Deadman segment of the megashear steps left along east-trending faults on the south side of Horse Prairie Basin, creating a small, almost 4.6-km-deep, Tertiary pull-apart graben beneath Horse Prairie. The fault zone then continues northwest to the south end of the Big Hole Basin where it is cut by or concealed beneath detachment faults of early Tertiary age (O'Neill and others, 2004). 


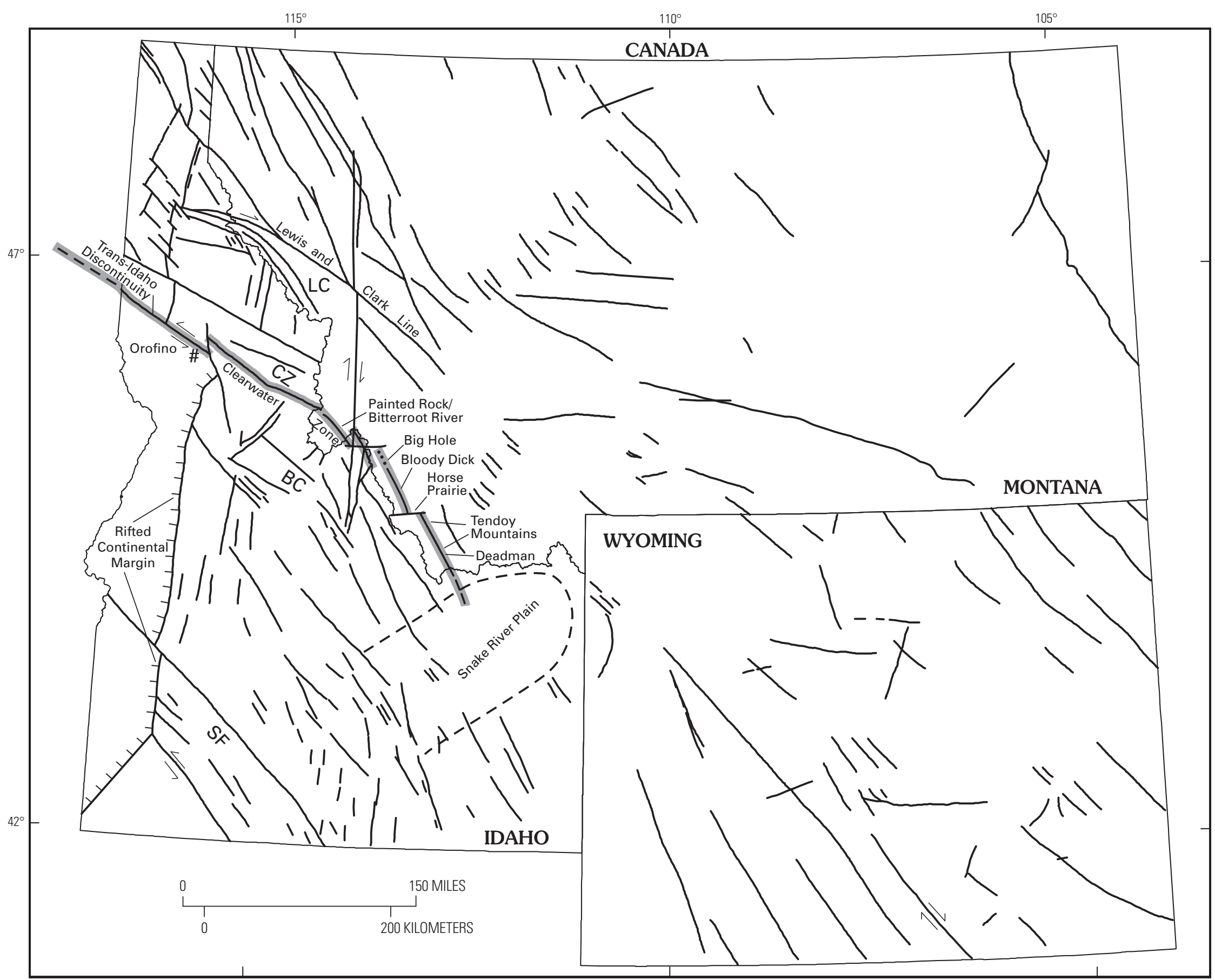



Figure 2. Northwest-trending faults in the northern Rocky Mountains, including the trace of the Great Divide megashear (screened band) and its interconnected fault segments (modified from Sims and others, 2004). BC, Big Creek zone; CZ, Clearwater zone; LC, Lewis and Clark line; SF, Snake fault zone. 
The originally defined Deadman fault is indeed a down-tothe-west normal fault that follows the trace of the southernmost part, the Deadman zone, of the Idaho-Montana megashear. Archean rocks east of the normal fault are sheared, cataclasized, and intruded by numerous mafic to silicic dike and vein systems in a zone more than $1.5 \mathrm{~km}$ wide. Faults and shears in these crystalline metamorphic and igneous rocks lie within (or along the east side of) the northwest-trending Deadman zone. Those faults and shears predate Cenozoic normal faulting and postdate the assembly of the Archean metamorphic rocks of the Wyoming Province of which they are a part.

The Bloody Dick segment of the megashear, previously interpreted to be a thrust fault zone (Coppinger, 1974; Ruppel and others, 1993), is a vertical zone of mylonitic rock more than $1.5 \mathrm{~km}$ wide. Stretching lineations in the mylonite are subhorizontal, plunging gently both northwest and southeast. This segment of the megashear shows both transpression and transtensional structures related to mylonitization and strikeslip displacement. A strongly sheared, 1-km-wide horst of Paleoproterozoic and Archean basement rocks remains caught between two strands of the fault zone. North of the horst is a small, elongate, pull-apart basin now filled with weakly consolidated sedimentary rocks of the Miocene to Eocene Bozeman Group (Coppinger, 1974; Ruppel and others, 1993).

The ages of relatively recent movements (late Tertiary) along the Deadman fault are fairly clear, but the original age of the fault zone and its earliest movement is interpreted to be Mesoproterozoic, coeval with sedimentation of the Belt and Lemhi strata. Mesoproterozoic rocks of questionable affinity (in segments of the Deadman-Bloody Dick fault zone where it steps left at Horse Prairie) suggest initial movement along the zone in the Mesoproterozoic. These anomalous rocks north of Horse Prairie and east of the Bloody Dick fault segment include a thick sequence of feldspathic quartzite that combines lithologic and stratigraphic characteristics of both the Lemhi Group and Belt Supergroup (Coppinger, 1974; Tysdal and others, 2005). We interpret these quartzites as a unique subfacies of the Missoula Group rocks-a syntectonic accumulation of clastic sediment deposited in a Mesoproterozoic pull-apart basin along a left-stepping releasing bend or accommodation zone of the megashear formed during Mesoproterozoic basin infilling.

Compelling evidence for large-scale left-lateral strike-slip displacement along the Deadman-Bloody Dick segment of the shear zone lies in the left-lateral offset of major throughgoing, crustal-scale basement structures. Both Paleoproterozoic and Archean rocks underlie the rugged ranges of southwest Montana. Exposures of these rocks reveal tectonic components of a Paleoproterozoic collisional orogen that underlies the 200-km-wide northeast-trending Great Falls tectonic zone (fig. 3) (O'Neill and Lopez, 1985; O'Neill, 1999). This 1.8-Ga collisional orogen extends from northeastern Montana to southcentral Idaho and reflects the suturing of the Archean Wyoming Province to the Medicine Hat Province of southern Alberta, British Columbia, and northwest Montana (O'Neill, 1999). The Tendoy Mountains (fig. 2), bounded on the southwest by the Deadman fault segment of the megashear, are underlain by several large exposures of crystalline basement rocks that are part of the Archean Wyoming Province. The Paleoproterozoic rocks on the southwest side of the main strand of the Deadman fault are not a part of the Archean Wyoming Province; the only known Paleoproterozoic rocks in this region comprise the accreted terrane within the 1.8-Ga Paleoproterozoic collisional orogen that bounds the Wyoming craton on the northwest. The northeast-trending Dillon shear zone (fig. 3), the tectonic boundary between cratonic and accreted terranes, lies $50 \mathrm{~km}$ northwest of this part of the Deadman fault zone. Based on the juxtaposition of accreted terrane within the collisional orogen against Archean cratonic rocks along the northwest-trending Deadman-Bloody Dick segment of the megashear, we interpret the strike-slip displacement along the megashear to be at least $50 \mathrm{~km}$ of left-lateral offset.

\section{Big Hole Segment}

The northwest continuation of the Bloody Dick segment of the megashear into the Big Hole Basin is largely concealed by more than $5 \mathrm{~km}$ of Quaternary and Tertiary sedimentary and volcanic rock. High-angle normal faults in Quaternary deposits along the east side of the Beaverhead Mountains (Ruppel and others, 1993) may reflect recurrent movement that exploits weakness along the concealed megashear that underlies Big Hole Basin fill.

Faults related to the megashear are exposed in the Big Hole Pass area, northwest of the Big Hole Basin; in this area the subhorizontal detachment fault of the Chief Joseph metamorphic core complex (Ruppel and O'Neill, 2003; O'Neill and others, 2004) is exposed (Lopez and others, 2005) as are rocks beneath the detachment. Mesoproterozoic strata beneath the detachment can be divided into two groups that are juxtaposed along the Dahlonega fault (fig. 2), a broad, irregular, east-trending fault zone. Rocks found only in Idaho, the Yellowjacket and middle Lemhi Group strata, are exposed south of the fault zone, but north of the fault zone white to light-gray feldspathic quartzites of uncertain affinity crop out (Lopez, 1982). These quartzites were mapped as Lemhi Group undifferentiated by Ruppel and others (1993) on the Dillon 2 degree quadrangle and more recently as undifferentiated Mesoproterozoic quartzite by Evans and Green (2003). Like the quartzite that underlies the left-stepping accommodation zone at Horse Prairie, rocks in the Big Hole Pass area represent a unique stratigraphic sequence that shares strong similarities with both Belt and Lemhi strata. One aspect of its uniqueness is the percentage of feldspar in these quartzites: these rocks carry both the "Belt" potassium feldspar suite intermixed with the "Lemhi" plagioclase suite (David Lindsey, U.S. Geological Survey, oral commun., 2007) These perplexing strata are restricted to the area north of a left-stepping accommodation zone; we interpret them to represent a hybrid Mesoproterozoic assemblage deposited in a pull-apart graben along a releasing bend of the Great Divide megashear. 




Figure 3. Northern Rocky Mountains showing location of the Great Falls tectonic zone (screened) and the left-lateral offset of the Dillon shear zone by the Great Divide megashear; Precambrian-cored basement uplifts are shaded tan (modified from Sims and others, 2004). Screened area, Great Falls tectonic zone. 


\section{Painted Rocks Segment}

Previous geologic investigations in the headwaters region of the West Fork of the Bitterroot River (fig. 2) did not recognize any strike-slip faulting (Berg, 1977; Fisk, 1969; Lund and others (1983). With the exception of Berg (1977), geologic maps of other reports did not distinguish between the various quartzites within the area. The Painted Rocks fault segment is well exposed only in the area of Painted Rocks Lake, where it separates Mesoproterozoic strata characteristic of the Lemhi Group rocks of Idaho on the southwest from Missoula Group quartzite and siltite on the northeast. The southeastern part of the fault places thick-bedded, light-gray quartzite of the Gunsight Formation of the Lemhi Group against middle and upper (?) Mount Shields Formation of the Belt Supergroup. Northwestward along the fault zone, the Gunsight and overlying Swauger formations are in fault contact with the Mount Shields Formation.

The Painted Rocks fault zone is $2-3 \mathrm{~km}$ wide; it records shearing, transposition, intrusion, and mylonitization of Mesoproterozoic sedimentary rocks. The rocks within the zone show variable amounts of shearing and subhorizontal stretching lineations on bedding plane surfaces and on shear surfaces. Intensity of shearing and mylonitization increases toward the central part of the shear zone. Shear zones are vertical near the middle of the zone and are more widely spaced and curviplanar away from the middle, where rock between the faults has been rotated and crushed.

\section{Clearwater Segment}

Most of the northwest-striking faults of the northern Rocky Mountains are coincident with narrow negative aeromagnetic anomalies (Sims and others, 2004; Sims and others, 2005). In addition to these correlative anomalies and known faults, there are three larger northwest-trending negative magnetic anomalies, two of which can be correlated with the large Lewis and Clark line (fig. 2) of west-central Montana and adjacent Idaho and with the Snake River-Wichita fault zone, more than 2,000 km long, which originates east of Colorado (Sims and others, 2005). A third anomaly, similar in size and intensity, was named the Clearwater fault zone (fig. 2) by Sims and others (2005); it trends west-northwest across central Idaho from the Painted Rocks segment of the megashear to Orofino in west-central Idaho. At its west end this aeromagnetic anomaly is colinear with the Trans-Idaho discontinuity (fig. 2), an inferred zone of transverse structures that Yates (1968) interpreted to represent a major continental-scale structure that offsets and separates sharply contrasting geologic terranes on the northeast and southwest. Yates (1968, p. 122) interpreted the discontinuity as a "strike-slip fault, or zone of faults, with left-lateral movement sense." The existence and location of this discontinuity was more precisely defined by Armstrong and others (1977), who mapped it as an abrupt $\mathrm{Sr}^{87} / \mathrm{Sr}^{86}$ isotope boundary between an island-arc accreted terrane on the southwest and a continental craton on the northeast. They traced this isotopic boundary as a narrow north-trending zone in southwest Idaho that turns abruptly to the west near Orofino, Idaho; at Orofino, the boundary intersects the Trans-Idaho discontinuity of Yates (1968) and follows it westward into east-central Washington. Armstrong and others (1977) concurred with Yates that the discontinuity must represent a left-lateral transform fault that is a major crustal boundary in the northwest cordillera of the United States.

\section{Summary}

The Great Divide megashear is a regional-scale shear zone that can be traced for more than $500 \mathrm{~km}$. It is a mappable, mylonitic shear zone as much as $3-8 \mathrm{~km}$ wide that extends northwestward from the Snake River Plain across extreme southwest Montana along and parallel to the Montana-Idaho state line, thence west-northwestward to connect with the Clearwater zone of Sims and others (2005) that crosses central Idaho, which in turn continues westward as the Trans-Idaho discontinuity of Yates (1968) into east-central Washington. Yates' discontinuity shows left-lateral offset of the Laurentian continental margin in Idaho and Washington on the order of several hundred kilometers; the left-lateral offset of the discontinuity is in the same sense as but greater than the observed $50 \mathrm{~km}$ minimum left-lateral offset of piercing points within the northeast-trending Paleoproterozoic collisional orogen (Great Falls tectonic zone) that is offset by the Great Divide megashear adjacent to the Continental Divide in extreme southwestern Montana.

The megashear first formed in Mesoproterozoic time and is interpreted to have influenced Mesoproterozoic sedimentation in Montana and Idaho. Mesoproterozoic Belt Supergroup and Lemhi Group strata are restricted to areas northeast and southwest of the megashear, respectively. Correlations between the two are difficult and subject to several interpretations; correlations are based on the assumption that the two were deposited in the same depositional basin. Workers in the region do agree that unique quartzite sedimentary facies within or immediately adjacent to the megashear share similar sedimentary environments of deposition with both the uppermost Belt and Lemhi strata. Our work has shown that these unique facies are restricted to small extensional, left-stepping, pull-apart basins that formed along the strike of the Great Divide megashear, which everywhere separates Belt and Lemhi rocks. The difficulties in correlation between Belt and Lemhi stratigraphic successions across the megashear suggest that the Belt and Lemhi Basins were separate depocenters during the majority of basin infilling and that direct correlations between the two are not possible. The youngest rocks, the Mount Shields Formation of the Missoula Group to the north and northeast and the Swauger and Lawson Creek Formations overlying the Lemhi Group to the southwest, are interpreted to have interfingered across the megashear during the later stages of deposition and basin infilling. 


\section{References Cited}

Armstrong, R.L., Taubeneck, W.H., and Hales, P.O., 1977, $\mathrm{Rb}-\mathrm{Sr}$ and $\mathrm{K}-\mathrm{Ar}$ geochronometry of Mesozoic granitic rocks and their isotopic composition, Oregon, Washington, and Idaho: Geological Society of America Bulletin, v. 88, p. $397-411$.

Berg, R.B., 1977, Reconnaissance geology of southernmost Ravalli County, Montana: Montana Bureau of Mines and Geology Memoir 44, 39 p.

Burchfiel, B.C., Cowan, D.S., and Davis, G.A., 1992, Tectonic overview of the Cordilleran orogen in the western United States, in Burchfiel, B.C., Lipman, P.W., and Zoback, M.L., eds., The Cordilleran orogen-Conterminous U.S.: Geological Society of America, The Geology of North America, v. G-3, Decade of North American Geology, p. 407-480. Coppinger, Walter, 1974, Stratigraphic and structural study of Belt Supergroup and associated rocks in a portion of the Beaverhead Mountains, southwest Montana and east-central Idaho: Oxford, Ohio, Miami University, Ph.D. dissertation, $224 \mathrm{p}$.

Evans, K.V., and Green, G.N., 2003, Geologic map of the Salmon National Forest and vicinity, Idaho: U.S. Geological Survey Geologic Investigations Series Map I-2765, scale $1: 100,000$.

Fisk, H.G., 1969, Painted Rocks Lake area, southern Ravalli County, Montana: Montana Bureau of Mines and Geology Special Publication 47, scale 1:48,000.

Foose, R.M., Wise, D.V., and Garbarini, G.S., 1961, Structural geology of the Beartooth Mountains, Montana and Wyoming: Geological Society of America Bulletin, v. 72, p. 1123-1172.

Garihan, J.M., Schmidt, C.J., and Karasevich, L.P., 1982, Road log for the Ruby Range, part of the Highland Range, and adjacent intermontane basins, southwest Montana, with emphasis on recurrent history, in Beaver, Patricia, ed., Tobacco Root Geological Society, 7th annual field conference, Guidebook, p. 45-68.

Harlan, S.S., Snee, L.W., and Geissman, J.W., 1990, Paleomagnetic and 40Ar/39Ar results from mafic dikes and basement rocks, southwest Montana: EOS: Transactions of American Geophysical Union, v. 71, p. 1297.

Lopez, D.A., 1982, Reconnaissance geologic map of the Gibbonsville quadrangle, Lemhi County, Idaho and Beaverhead County, Montana: U.S. Geological Survey Miscellaneous Field Studies Map MF-1446, scale 1:24,000.

Lopez, D.A., O’Neill, J.M., and Ruppel, E.T., 2005, Preliminary geologic map of the Big Hole Pass-Lost Trail Pass area, southwestern Montana: Montana Bureau of Mines and Geology Open-File Report 522, scale 1:24,000.
Lund, Karen, Rehn, W.M., and Holloway, C.D., 1983, Geologic map of the Blue Joint Wilderness study area, Ravalli County, Montana, and the Blue Joint Roadless Area, Lemhi County, Idaho: U.S. Geological Survey Miscellaneous Field Investigations Map MF-1557-B, scale 1:50,000.

O’Neill, J.M., 1995, Table Mountain Quartzite and Moose Formation (new names) and associated rocks of the Middle Proterozoic Belt Supergroup, Highland Mountains, southwestern Montana: U.S. Geological Survey Bulletin 2121-A, 26 p.

O’Neill, J.M., 1999, The Great Falls tectonic zone, Idaho and Montana-An early Proterozoic collisional orogen beneath and south of the Belt Basin, in Berg, R.B., Belt Symposium III: Montana Bureau of Mines and Geology Special Publication 112 , p. 222-228.

O’Neill, J.M., Ferris, D.C., Schmidt, C.J., and Hanneman, D.L., 1986, Recurrent movement along northwest-trending faults at the southern margin of the Belt Basin, Highland Mountains, southwestern Montana, in Roberts, S.M., ed., Belt Supergroup: Montana Bureau of Mines and Geology Special Publication 94, p. 208-216.

O’Neill, J.M., and Lopez, D.A., 1985, Character and regional significance of the Great Falls tectonic zone, east-central Idaho and west-central Montana: American Association of Petroleum Geologists Bulletin, v. 69, 437-447.

O’Neill, J.M., Lopez, D.A., and Ruppel, E.T., 2004, Newly recognized Chief Joseph metamorphic core complex and younger structures in the north-central Beaverhead Mountains, Idaho and Montana-Expanding the temporal limits of post-contractional extension in the northern Rocky Mountains [abs.]: Geological Society of America Abstracts with Program, v. 37, no. 6, p. 4.

Pardee, J.T., 1950, Late Cenozoic block faulting in western Montana: Geological Society of America Bulletin, v. 61, p. 359-406.

Reid, R.R., 1957, Bedrock geology of the north end of the Tobacco Root Mountains, Madison County, Montana: Montana Bureau of Mines and Geology Memoir 36, 27 p.

Reynolds, M.W., 1979, Character and extent of Basin-Range faulting, western Montana and east-central Idaho, in Newman, G.W., and Goode, H.D., eds., RMAG/UGA Basin and Range Symposium and Great Basin Field Conference, Rocky Mountain Association of Geologists and Utah Geological Association, p. 185-193. [available from Utah Geological Association]

Ruppel, E.T., 1978, Medicine Lodge thrust system, east-central Idaho and southwest Montana: U.S. Geological Survey Professional Paper 1031, 23 p.

Ruppel, E.T., 1982, Cenozoic block uplifts in east-central Idaho and southwest Montana: U.S. Geological Survey Professional Paper 1224, 24 p. 
Ruppel, E.T., 1985, The association of Middle Cambrian rocks and gold deposits in southwestern Montana: U.S. Geological Survey Open-File Report 85-207, 26 p.

Ruppel, E.T., and Lopez, D.A., 1984, The thrust belt in southwest Montana and east-central Idaho: U.S. Geological Survey Professional Paper 1278, 41 p.

Ruppel, E.T., and O’Neill, J.M., 2003, Early Tertiary detachment faulting in southwest Montana and east-central Idaho [abs.]: Northwest Geology, v. 32, p. 222-223.

Ruppel, E.T., O’Neill, J.M., and Lopez, D.A., 1993, Geologic map of the Dillon 1x2 degree quadrangle, Idaho and Montana: U.S. Geological Survey Miscellaneous Field Investigations Series Map I-1803-H, scale 1:250,000.

Schmidt, C.J., and Dresser, H.W., 1986, Late Cenozoic structural inversion in a region of small extensional strain, southwestern Montana: Geological Society of America Abstracts with Program, v. 16, no. 6, p. 646-647.

Schmidt, C.J., and Garihan, J.M., 1983, Laramide tectonic development of the Rocky Mountain foreland of southwestern Montana, in Lowell, J.D., and Gries, R., eds., Rocky Mountain foreland basins and uplifts: Rocky Mountain Association of Geologists Symposium, p. 271-294.

Schmidt, C.J., and Garihan, J.M., 1986, Middle Proterozoic and Laramide tectonic activity along the southern margin of the Belt Basin, in Roberts, S.M., ed., Belt Supergroup: Montana Bureau of Mines and Geology Special Publication 94, p. 217-236.

Schmidt, C.J., and Hendrix, T.E., 1981, Tectonic controls for thrust belt and Rocky Mountain foreland structures in the northern Tobacco Root Mountains-Jefferson Canyon area, southwestern Montana, in Tucker, T.E., ed., SW Montana: Montana Geological Society, 1981 field conference and symposium, Guidebook, p. 167-180.

Schmidt, C.J., and O’Neill, J.M., 1982, Structural evolution of the southwest Montana transverse zone, in Powers, R.B., ed., Geologic studies of the Cordilleran thrust belt: Rocky Mountain Association of Petroleum Geologists, p. 167-180.

Scholten, Robert, Keenmon, K.A., and Kupsch, W.O., 1955, Geology of the Lima region, southwestern Montana and adjacent Idaho: Geological Society of America Bulletin, v. 66 , p. 345-404.

Sims, P.K., Lund, Karen, and Anderson, E., 2005, Precambrian crystalline basement map of Idaho-An interpretation of aeromagnetic data: U.S. Geological Survey Scientific Investigations Map 2884, scale 1:1,000,000.
Sims, P.K., O’Neill, J.M., Bankey, Viki, and Anderson, E., 2004, Precambrian basement geologic map of Montana-An interpretation of aeromagnetic anomaly map: U.S. Geological Survey Scientific Investigations Map 2829, scale $1: 1,000,000$.

Skipp, Betty, and Hait, M.H., Jr., 1977, Allochthons along the northwest margin of the Snake River Plain, Idaho: Wyoming Geological Association, 29th annual field conference, Guidebook, p. 499-515.

Stickney, M.C., and Bartholomew, M.J., 1987, Seismicity and late Quaternary faulting of the northern Basin and Range Province, Montana and Idaho: Seismological Society of America Bulletin, v. 77, p. 1602-1625.

Swanson, R.W., 1970, Mineral resources of Permian rocks of southwest Montana: U.S. Geological Survey Professional Paper 313-E, p. 661-777.

Thorson, J.P., 1984, Suggested revisions of the lower Belt Supergroup stratigraphy in the Highland Mountains, southwestern Montana, in Hobbs, W.S., ed., The Belt: Montana Bureau of Mines and Geology Special Publication 90, p. $10-12$.

Tysdal, R.G., Lindsey, D.A., Lund, K.I., and Winkler, G.R., 2005, Alluvial facies, paleocurrents, and source of the Mesoproterozoic Gunsight Formation, east-central Idaho and southwestern Montana, chap. B, in O'Neill, J.M., and Tysdal, R.G., eds., Stratigraphic studies in southwestern Montana and adjacent Idaho_-Lower Tertiary Anaconda Conglomerate and Mesoproterozoic Gunsight Formation: U.S. Geological Survey Professional Paper 1700-B, p. 21-39.

Winston, Don, 1986, Middle Proterozoic tectonics of the Belt Basin, western Montana and northern Idaho, in Roberts, S.M., ed., Belt Supergroup-A guide to the Proterozoic rocks of western Montana and adjacent areas: Montana Bureau of Mines and Geology Special Publication 94, p. 245-257.

Wooden, J.L., Vitaliano, C.J., Koehler, S.W., and Ragland, P.C., 1978, The late Precambrian mafic dikes of the southern Tobacco Root Mountains, Montana-Geochemistry, Rb-Sr geochronology, and relationships to Belt tectonics: Canadian Journal of Earth Science, v. 15. p. 467-479.

Yates, R.G., 1968, The Trans-Idaho discontinuity: International Geological Congress, 23rd, Prague, 1968, Proceedings, v. 1, p. 117-123. 


\section{Blackbird Fe-Cu-Co-Au-REE Deposits}

By Arthur A. Bookstrom, Craig A. Johnson, Gary P. Landis, and Thomas P. Frost

Chapter B of

Metallogeny of Mesoproterozoic Sedimentary Rocks in Idaho and Montana - Studies by the Mineral Resources Program, U.S. Geological Survey, 2004-2007

Edited by J. Michael O'Neill

Open-File Report 2007-1280-B 


\section{Contents}

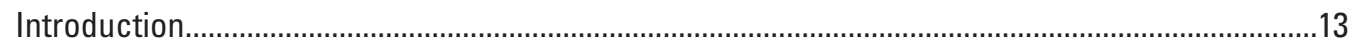

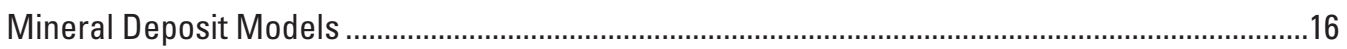

Postmetamorphic Epigenetic Deposit Model ....................................................................16

Synsedimentary, Submarine Volcanic-Related Deposit Model ................................................16

Syngenetic Versus Epigenetic Mineralization .....................................................................16

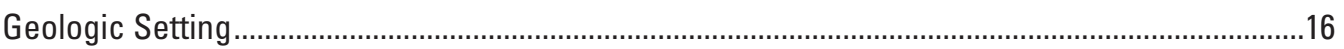

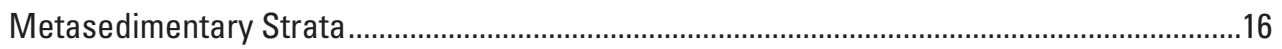

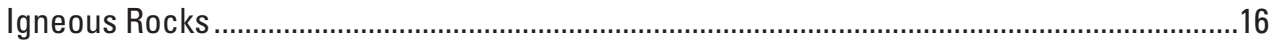







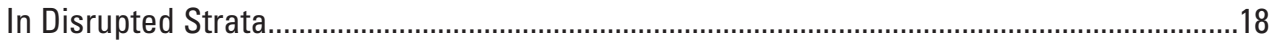

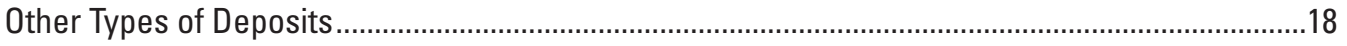

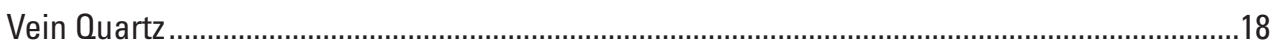

Discordant Uncle Sam and South Idaho Ore Zones ............................................................18

Late Discordant Dandy Zone .............................................................................................

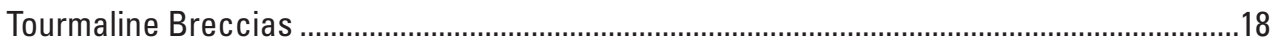

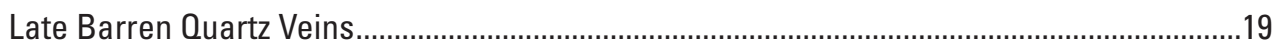

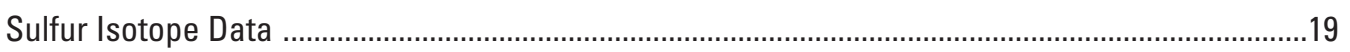

History of Mineralization, Deformation, and Metamorphism .......................................................19

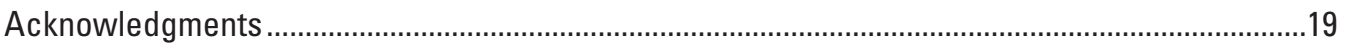

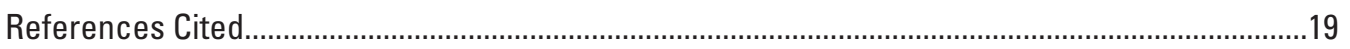

\section{Figures}

1. Index map showing location of Blackbird mine in east-central Idaho ...........................13

2. Blackbird mine and surrounding area, showing distribution of geologic units ..............14 


\title{
Blackbird Fe-Cu-Co-Au-REE Deposits
}

\author{
By Arthur A. Bookstrom, Craig A. Johnson, Gary P. Landis, and Thomas P. Frost
}

\section{Introduction}

The Blackbird deposits of iron (Fe)-, copper $(\mathrm{Cu})-$, cobalt (Co)-, gold (Au)-, and rare-earth-element (REE)-bearing minerals are in east-central Idaho, about 34 kilometers $(\mathrm{km})$ west of Salmon, Idaho; they lie near the midpoint of the Idaho cobalt belt, which extends at least $50 \mathrm{~km} \mathrm{~N} .40^{\circ}-45^{\circ} \mathrm{W}$. across the Salmon River Mountains (fig. 1). Most mines and prospects are within or near the banded siltite unit of the Mesoproterozoic Apple Creek Formation, which crops out between northweststriking thrust faults of Cretaceous age (Slack, fig. 1, this volume).

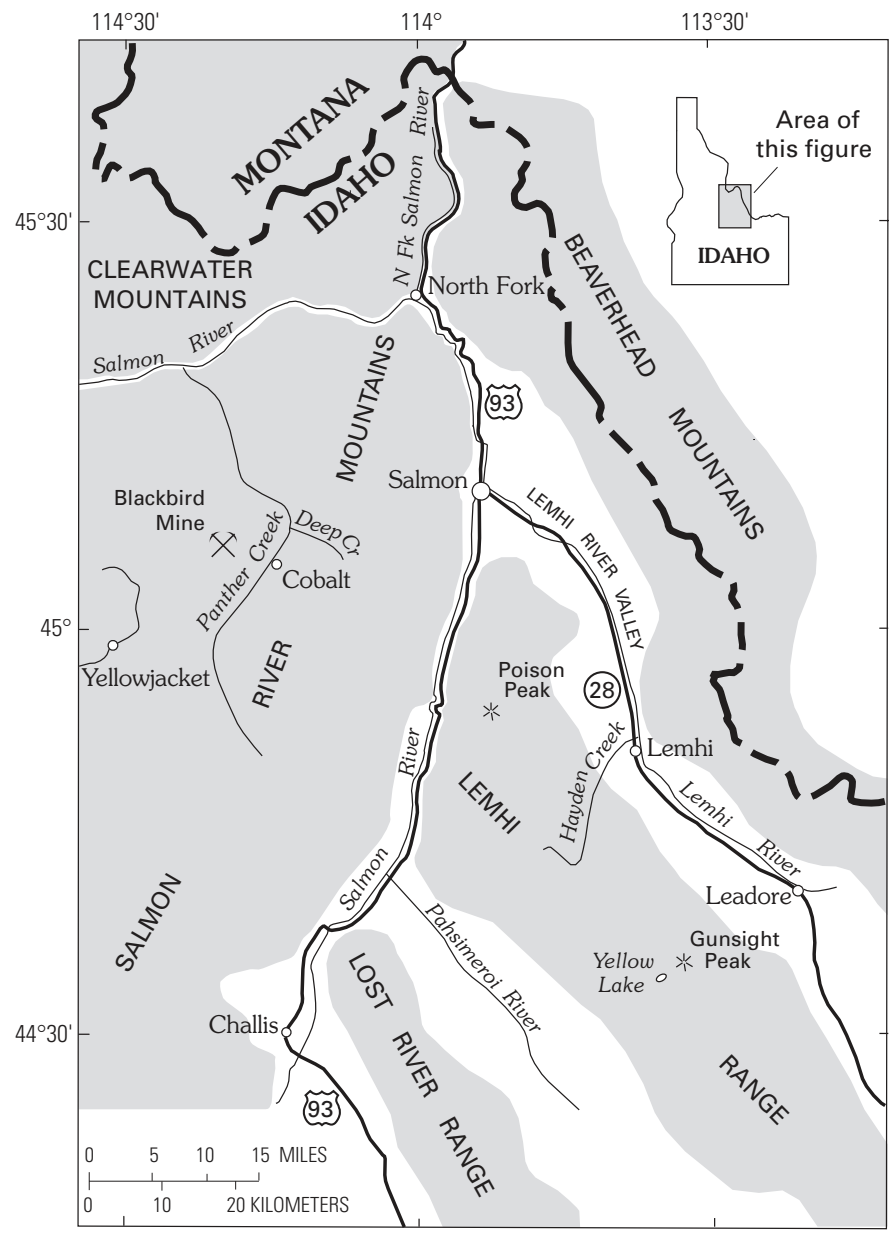

Figure 1. Location of Blackbird mine in east-central Idaho.
The Blackbird mine complex consists of extensive underground workings on the Dandy, Idaho, Chicago, and Brown Bear ore zones and an open pit on the Blacktail ore zone (fig. 2). Past production from the Blackbird mine complex amounts to approximately 1.7 million metric tonnes (Mt) of high-sulfide Co-Cu ore, mined mostly between 1945 and 1966, from which about 10 thousand metric tonnes (kt) of $\mathrm{Co}$ and $32 \mathrm{kt}$ of $\mathrm{Cu}$ were recovered (E.A. Magill, U.S. Bureau of Mines, unpub. data, 1966; Hughes, 1990). Known resources, including those of the Ram zone, discovered in 1994-95 by Formation Capital Corporation, are approximately $11.7 \mathrm{Mt}$ of ore containing 77 $\mathrm{kt}$ of $\mathrm{Co}$ and $120 \mathrm{kt}$ of $\mathrm{Cu}$ at average grades of 0.7 percent $\mathrm{Co}$ and 1.1 percent $\mathrm{Cu}$. About 3.7 Mt of ore in the Ram zone also contain about 2 metric tonnes ( $\mathrm{t}$ ) of $\mathrm{Au}$ at an average grade of $0.55 \mathrm{~g} \mathrm{Au} / \mathrm{t}$ (Formation Capital Corporation, 2007). Most major ore zones extend below mining depths of 100 to $200 \mathrm{~m}$, and exploration drilling indicates that ore zones continue downward to more than $100 \mathrm{~m}$ below that. On the basis of this and other information, it has been suggested that the Blackbird district may have an ultimate potential of about $50 \mathrm{Mt}$ of ore (G.H. Hughes, Formation Capital Corporation, 2007). John Slack (2006) recently discovered locally abundant monazite and xenotime in cobaltite-rich ores and suggested that these minerals could be recovered for their light and heavy REE.

Past production came mostly from massive to sulfide-rich and sulfide-arsenide-rich ores near the center of the Blackbird mine complex. Mine workings in the oxidizing vadose zone were backfilled with tailings containing iron-bearing sulfides. Continuing interaction of vadose water with these oxidizing tailings produces acidic mine-drainage waters with thousands of milligrams per liter of copper and sulfate and hundreds of milligrams per liter of iron and cobalt (Evans and others, 1995). Mine-drainage water is now being captured and treated to raise $\mathrm{pH}$ and remove dissolved metals. Proposed production would come from northern, relatively low-sulfide ore zones. Nearly all metal sulfides would be recovered, and the sand fraction of tailings would be placed underground as paste (Joe Scheuering, Formation Capital Corporation, oral commun., 2007).

Figure 2 (following page). Blackbird mine and surrounding area, showing distribution of geologic map units, garnet-bearing rocks, ore zones, and selected structural features, mines, prospects, and streams (after Vhay, 1948; Noranda Exploration, Inc., unpub. data, 1985; Nash and Hahn, 1989; and Formation Capital Corporation, unpub. data, 2005). 


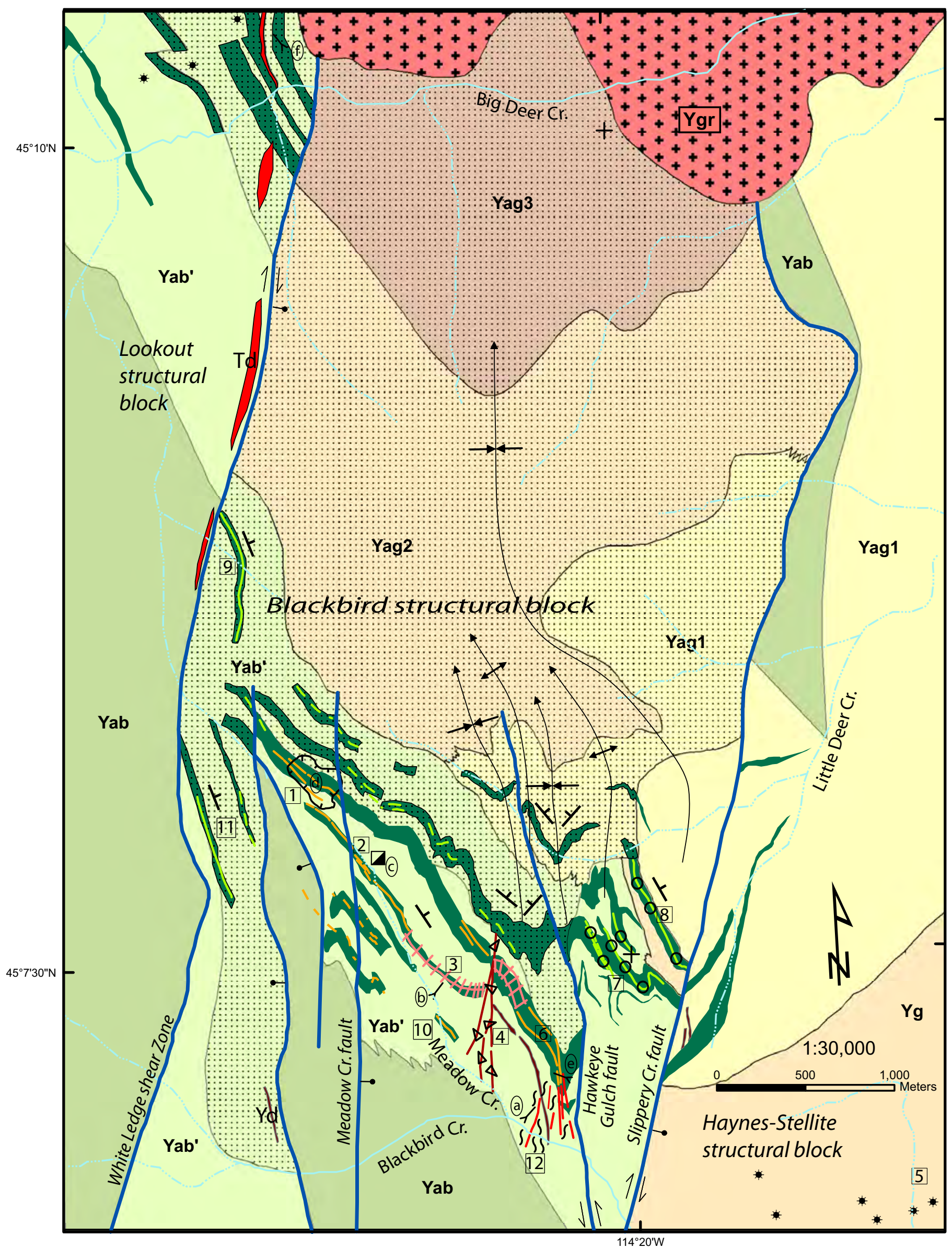




\section{EXPLANATION}

Tertiary igneous rocks

$\mathrm{Td}$ Dikes, felsic

Mesoproterozoic igneous rocks

$+Y^{+} \mathrm{gr}^{+}$Granite, gneissic (1.37 Ga)

Yd Dikes, mafic

Mesoproterozoic metasedimentary strata
Mine Workings

(a) Blackbird (6850 ft elev.)

(b) Calera (7100 ft elev.)

(c) Brown-Bear shaft

(d) Blacktail pit

(e) New Hawkeye (7080 ft elev.)

f Tinkers Pride prospect

... Garnet-bearing rocks +/- chloritoid +/- cordierite

$\mathrm{Yg}$ Gunsight Formation - Metasandstone and minor metashale

Yag Apple Creek Formation and (or) Gunsight Formation

Yag3 unit 3 -- Schistose metasandstone and minor schist

Yag2 unit 2 -- Banded schistose metasandstone and schist

Yag1 unit 1 -- Biotitic metasandstone

Yab Apple Creek Formation, banded-siltite unit

-- meta-siltite and meta-argillite

Yab" Banded siltite with many interlayers of biotite rock

Yab' Banded siltite with few interlayers of biotite rock

\section{Ore Zones}

1. Blacktail

2. Brown Bear

3. Chicago

4. Dandy

5. Haynes-Stellite

6. Idaho

7. Merle

8. Northfield

9. Ram

10. St. Joe

11. Sunshine

12. Uncle Sam
Ore-Zone Types

* Tourmaline breccia

(ore zone)

$\checkmark$ \& Discordant, massive-sulfide breccia

$\simeq \approx$ Discordant, shear-zone hosted

$\mapsto$ H|H Stratabound and discordant

(prospect)

Stratabound in silica-rock sequence

- 0 Stratabound in disrupted sequence

Stratabound in biotite-rock sequence

\section{Structural Features}

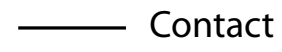

i. Normal fault -- Bar and ball on downthrown side

Y Strike and dip

of bedding

$\longleftarrow$ Axis of syncline

$\stackrel{\uparrow}{\downarrow}$ Axis of anticline

$\rightleftharpoons$ Strike-slip fault, right-lateral offset
Streams

Perennial

Ephemeral
Cultural Features






\section{Mineral Deposit Models}

\section{Postmetamorphic Epigenetic Deposit Model}

Vhay (1948) mapped and described Blackbird ore zones as discontinuous veins and lenses in northwest-striking shear zones with moderate northeast dips and in north- to northeast-striking shear zones with steep dips. He also noted that some ore lenses plunge north, parallel to north-plunging folds. Anderson (1947), Vhay (1948), and Bennett (1977) interpreted the Blackbird deposits as postmetamorphic, epigenetic, hydrothermal vein and replacement deposits controlled by preore folds and shear zones. They suggested that ore-bearing hydrothermal fluids emanated from a nearby granite batholith, a part of which is shown in figure 2 . They considered the batholith to be part of the Cretaceous Idaho batholith, which implied a Cretaceous age for the supposedly related Blackbird ores.

\section{Synsedimentary, Submarine Volcanic-Related Deposit Model}

Hughes (1983) recognized that northwest-striking, moderately dipping ore zones of the Blackbird mine area are stratabound in sequences of biotite-rich beds (fig. 2). He noted that the biotite-rich beds, which host much of the stratabound ore, are chemically similar to dikes of a coextensive swarm of mafic dikes, and he suggested that the biotite-rich rocks are metamorphosed submarine mafic tuffs. He described the Blackbird deposits as synsedimentary hydrothermal deposits, related to submarine volcanic activity along the northwest-trending axis of a tectonically active rift that was simultaneously receiving siliciclastic turbidites from its margins. This model was adopted and elaborated by Modreski (1985), Earhart (1986), Eiseman (1988), Nash (1989a), Nash and Hahn (1989), Hughes (1990), Nold (1990), Nash and Connor (1993), and Bending and Scales (2001).

\section{Syngenetic Versus Epigenetic Mineralization}

Eiseman (1988) cited cobaltite concentrations along bedding planes in silica-rich strata as evidence for syngenetic cobaltite mineralization by chemical-exhalative precipitation. However, Jerry Zieg (NovaGold Resources, Inc., oral commun., 2004) cited the lack of finely laminated beds of massive sulfides as evidence that most Blackbird ores formed not by chemical-exhalative precipitation from the water column but rather by selective epigenetic replacement of favorable host strata. Nash (1989a), and Nash and Hahn (1989) cited concentrations of cobaltite and chalcopyrite in disrupted strata as evidence of epigenetic mineralization of strata that were disrupted during burial and solidification.

\section{Geologic Setting}

The fault-bounded Blackbird structural block of Vhay (1948) contains the pervasively folded and sheared metasedimentary strata that host the stratabound and discordant ore zones of the Blackbird mine area (fig. 2). Host strata historically were assigned to the Yellowjacket Formation but are now assigned to the banded siltite unit of the Apple Creek Formation, which consists of about 2,000 m of gray siltite and argillite. In the Blackbird mine area, siltite layers commonly retain sedimentary structures, but argillitic layers generally are metamorphosed to biotitic phyllite or schist.

\section{Metasedimentary Strata}

Most of the 2,000-m-thick banded siltite unit consists of interlaminated siltite and dark-gray argillite. About 4,000 m of relatively thick-bedded quartzite, siltite, and gray argillite of the Gunsight Formation overlie the banded siltite unit, which is underlain about $8,000 \mathrm{~m}$ of gray siltite, argillite, quartzite, local diamictite, and minor calc-silicate rock of the Apple Creek, Hoodoo, and Yellowjacket Formations (Evans and Green, 2003). Correlation of this package of units with the upper Piegan Group and the presence in these formations of detrital zircons dated about 1450 Ma require very rapid deposition of these strata in about 10 m.y., between about 1455 and $1445 \mathrm{Ma}$ (Link and others, 2007).

In the trough of a north-plunging syncline north of the Blackbird mine area, metasiltite and phyllite of the bandedsiltite unit are overlain by biotitic metasandstone, banded schistose metasandstone with subordinate garnet-schist interlayers, and thick-bedded schistose metasandstone with subordinate garnet-biotite schist interlayers (fig. 2). Evans and Green (2006) tentatively assigned these strata to the Apple Creek Formation, undivided, but we suggest that they are correlative with the Gunsight Formation, because they are sandy and they overlie banded siltite (fig. 2).

\section{Igneous Rocks}

Metamorphosed mafic dikes are common in and around the Blackbird mine area, but only a few of the larger dikes crop out. Vhay (1948) mapped many mafic dikes underground. Most cut ore zones, but some are cut by mineralized shear zones in the Uncle Sam zone (fig. 2). Some mafic dikes contain albite \pm sodic amphibole, indicative of spilitization, which implies that some mafic dikes were emplaced into wet sediments saturated with saline connate water. Thin dikes and chilled margins of thicker dikes are commonly altered and metamorphosed to biotite phyllite or schist, similar to that of biotite-rock layers. Nash and Hahn (1989) noted that mafic dikes are compositionally similar to biotite-rock layers, and they suggested that mafic dikes represent subvolcanic mafic magmas that erupted to supply mafic tuff to biotite-rock 
layers, provided heat to drive the Blackbird submarine hydrothermal system, and may have contributed copper and cobalt to the hydrothermal system.

A large pluton of Mesoproterozoic granite and augen gneiss $(1.37 \mathrm{Ga})$ with an associated mafic intrusive complex postdates the development of folds in its host metasedimentary strata north and east of the Idaho cobalt belt (Evans and Zartman, 1990; Doughty and Chamberlain, 1996; Evans and Green, 2003). Figure 2 shows a part of this granite pluton north of the Blackbird mine. Intrusions of OrdovicianCambrian, Cretaceous, and Eocene ages and volcanic rocks of Eocene age also crop out in the Salmon River Mountains (Evans and Green, 2003).

\section{Stratabound Deposits}

\section{In Biotite Rock}

Several major stratabound ore zones of the Blackbird mine area are hosted in sets of multiple biotite-rock layers, each less than about 30 centimeters $(\mathrm{cm})$ thick, interlayered with banded siltite (fig. 2). Biotite rock consists mostly of iron-rich biotite (annite), which also is also rich in potassium and chlorine (Nash, 1989b). In addition, biotite rock contains variably minor amounts of quartz, albite, and microcline; trace amounts of apatite, zoisite, tourmaline, ilmenite, and zircon; and locally abundant scapolite spherules (Connor and others, 1991; Nash and Connor, 1993). Much of the quartz in biotiterock layers is in subordinate beds of granular mosaic quartz, similar to that of the silica-rock layers that host the Sunshine and Ram zones.

Hughes (1993) interpreted biotite-rock layers as mafic tuffs rather than mafic sills, because they tend to have somewhat gradational contacts with overlying and underlying banded siltite. Nash (1989b) suggested that biotite rock formed by reaction of mafic volcaniclastic strata with potassium- and chlorine-rich fluid at temperatures appropriate for biotite formation. Nash and Hahn (1989) interpreted biotite rock as a metamorphosed hybrid of mafic tuff, clastic sediments, and hydrothermal constituents. Nash and Connor (1993) interpreted biotite rock as metamorphosed chemical sedimentary silicate-facies iron formation, rich in potassium and chlorine.

Zircon, ilmenite, and tourmaline grains in biotite rock probably are detrital. Nash (1989b) interpreted locally abundant spherules of sodium- and chlorine-rich scapolite as evidence for highly saline pore water during burial and lithification. Biotite rock is locally silicified or tourmalinitized (or both). Biotite rock that hosts stratabound ore zones contains cobaltite, chalcopyrite, and pyrite. Postore garnet, chloritoid, muscovite, and chlorite are locally abundant in metamorphosed biotite rock. Thermally metamorphosed biotite rock consists of randomly oriented biotite platelets, but dynamothermally metamorphosed biotite rock is phyllitic to schistose.
Cobaltite-rich ore in biotite phyllite from the Brown Bear and Blacktail zones (fig. 2) is pervasively folded and sheared. In one ore sample, rod-like concentrations of cobaltite parallel fold axes, but on a face cut perpendicular to fold axes, cobaltite grains are equant and appear to be stacked perpendicular to layering. In another sample, cobaltite is concentrated in shear bands around augen-shaped clasts of biotite rock and silica rock. In an ore sample with incipient phyllonitic fabric, parallel layers of semimassive cobaltite are connected by S-shaped diagonal cobaltite stringers in the manner of S-C fabric, which is generated by intense ductile shearing according to Barker (1998).

Ore samples from the stratabound Chicago zone contain cobaltite in disseminations, layer-like concentrations, stringers, and pods, bounded by biotite phyllite. Some layer-like concentrations of ore minerals contain augen-shaped clasts of biotite phyllite, granular mosaic quartz, and vein quartz. Some cobaltite rims minor safflorite, and some chalcopyrite is interstitial to cobaltite. With increasing proximity to discordant massive sulfide breccias of the Dandy zone, ores hosted in biotite-rock strata contain increasing proportions of pyrite, pyrrhotite, and marcasite.

\section{In Silica Rock}

Silica-rock layers host the stratabound Sunshine and Ram ore zones and several stratabound prospects in the upper northern and western parts of the Blackbird mine area (fig. 2). These layers consist mostly of quartz with a sugary, granularmosaic texture, similar to that of metachert or metamorphosed siliceous exhalite and unlike that of metamorphosed feldspathic metasandstone. In silica-hosted ores of the Sunshine zone, Eiseman (1988) reported cobaltite, chalcopyrite, pyrite, and traces of native gold, silver, bismuth, bismuthinite, and millerite. She also described bedding-parallel laminae in silica-rock layers, which she interpreted as mineral accumulations on bedding planes. Examples are micaceous laminae with streaks of detrital ilmenite and zircon, delicate graphitic laminae, and laminae of cobaltite grains. She cited cobaltite grains on bedding planes in silica rock as evidence for precipitation and settling of submarine-exhalative hydrothermal cobaltite from the water column.

Cobaltite also occurs as sparse to semimassive disseminations in silica rock. In one sample, subrounded lumps of silica rock with disseminated cobaltite are surrounded by a matrix of silica rock with higher concentrations of disseminated cobaltite. This arrangement may indicate that mineralization occurred before and after the silica rock was disrupted. Another sample contains cobaltite in layer-parallel streaks and also in a zone of chevron-like crumples, which may indicate concentration of cobaltite into small-scale fold axes during postore dynamothermal metamorphism. Cobaltite inclusions are present in some dark-red iron- and aluminum-rich almandine garnets in the Sunshine zone, which indicates that cobaltite was deposited before garnets formed during postore metamorphism (Eiseman, 1988). 
If biotite rock has a mafic tuff component and silica rock is hydrothermal siliceous exhalite, the close association of silica rock with biotite rock probably indicates that both are related to submarine volcanism. This hypothesis is supported by results from analysis of helium trapped in granular mosaic silica rock from the Sunshine zone, which yields helium isotope ratios indicative of remnant hydrothermal fluid that is highly enriched in mantle derived ${ }^{3} \mathrm{He}$, as is helium from modern mid-ocean ridge basalt, as characterized by Ballentine and others (2000).

\section{In Disrupted Strata}

Mineralized disrupted strata are common in drill core from the Blackbird, Blackpine, and Iron Creek areas, and disharmonic intrastratal folding, indicative of synsedimentary slumping, also is common in the vicinity of mineralized zones. Nash (1989a, p. 1) described disruption structures as "characterized by retextured sediment, loss of bedding features, lump breccia, and probably bedding-plane slips-all probably produced by liquefaction, fluidization, and submarine sliding of unconsolidated sediment." Relatively angular fragments in disrupted strata at Blackpine may indicate that disruption also occurred in consolidated strata. Nash and Hahn (1989) described quartz and siderite in the matrix of cobaltite-bearing lump breccias of the Merle zone, and they reported that fluid inclusions in such quartz have filling temperatures between $275^{\circ}$ and $375^{\circ} \mathrm{C}$ and contain halite, sylvite, and unidentified daughter minerals, some of which did not dissolve at the filling temperature.

Samples of mineralized disrupted strata from the Merle zone contain disseminated cobaltite and chalcopyrite in breccia with lumps of biotite and sugary silica rock in a biotite-rich matrix that wraps around the lumps. In such breccia, cobaltite is disseminated in lumps and matrix but is concentrated along the rims of lumps and in braided stringers between lumps. We also recognize similar remnants of disruption features in some samples from the stratabound Chicago, Idaho, Brown Bear, Blacktail, and Sunshine zones.

\section{Other Types of Deposits}

\section{Vein Quartz}

Whitish vein quartz with conchoidal fracture and greasy luster probably was deposited before, during, and after deformation of stratabound ore zones hosted in biotite rock. Stratabound ores of the Chicago, Brown Bear, and Blacktail zones contain deformed augen-like fragments of vein quartz. Semiconcordant pods of vein quartz in the Hawkeye workings have irregular chalcopyrite masses in banded siltite along their margins. Pods of vein quartz in the Chicago zone cut stratabound cobaltite ore but contain irregular masses of chalcopyrite and siderite. Deformed strata are cut locally by planar, discordant, steeply dipping quartz veins and veinlets, containing cobaltite \pm chalcopyrite \pm siderite. Such undeformed planar veins and veinlets probably formed after folding and shearing of stratabound ores hosted in biotite-rock layers.

\section{Discordant Uncle Sam and South Idaho Ore Zones}

Mineralized shear zones of the Uncle Sam and South Idaho zones strike north to northeast, dip steeply, and crosscut bedding in tightly folded metasedimentary strata beneath and within the stratabound Idaho zone (fig. 2). These mineralized shear zones host lenses, veins, veinlets, and stringers that contain pyrite, chalcopyrite, and cobaltite (Vhay, 1948). Alteration envelopes around these mineralized shear zones also contain pyrite, chalcopyrite, and cobaltite in silicified and chloritized host rocks, consisting mostly of banded siltite and disrupted strata (S.G. Peters, U.S. Geological Survey, unpub. data, 1980).

\section{Late Discordant Dandy Zone}

Dike-like discordant massive sulfide breccias of the Dandy zone strike north to northeast, dip steeply, and cut the stratabound Chicago and Idaho zones from below (fig. 2). The massive sulfide matrix of these breccias, which composes about 90 percent of their mass, consists of pyrrhotite, pyrite, marcasite, minor chalcopyrite, and rare cobaltite. Semirounded clasts of vein quartz and biotite-rock compose about 10 percent of the mass of these breccias. Some of the biotite-rock clasts contain abundant disseminated cobaltite.

Near the intersection of the Calera drift with the Chicago zone, a steeply dipping dike or vein of Dandy-type massive sulfide breccia cuts stratabound cobaltite ore of the Chicago zone. Near the Dandy zone, ores of the Chicago and Idaho zones contain abundant pyrite, pyrrhotite, and marcasite, but the proportion of these minerals decreases laterally from the Dandy zone. Thus it appears that these minerals were added to preexisting stratabound cobaltite ores by hydrothermal fluids delivered by late massive sulfide breccias of the Dandy zone.

\section{Tourmaline Breccias}

Tourmaline breccias are composed of black microcrystalline tourmaline (schorl) and clasts of host rocks and vein quartz. They occur as discordant pipes and dikes but also as locally concordant bodies. Some tourmaline breccias contain local concentrations of finely disseminated cobaltite and chalcopyrite. The ore-bearing Haynes-Stellite breccia cuts sandy strata of the Gunsight Formation southeast of the Blackbird mine (fig. 2). 


\section{Late Barren Quartz Veins}

Late barren quartz veins and pods with no associated ore minerals or alteration products cut metamorphosed ore zones and are widely distributed in siliciclastic country rocks (Roberts, 1953). Helium trapped in late vein quartz from the Sunshine zone is typical of radiogenic helium from continental crust, as characterized by Ballentine and others (2000).

\section{Sulfur Isotope Data}

Sulfur isotope data collected for this study indicate that Blackbird ore minerals have delta ${ }^{34} \mathrm{~S}_{\mathrm{VCDT}}=7-9$ per mil. These isotopic compositions are consistent with an origin in a seafloor hydrothermal system, hosted either in sedimentary or volcanic rocks. Sulfides from such systems normally have delta ${ }^{34} \mathrm{~S}$ values between basaltic sulfur ( 0 per mil) and contemporaneous seawater sulfate (14-18 per mil during the Mesoproterozoic) (Strauss and Schrieber, 1990). Such isotopic compositions also would be consistent with a deep-seated ore-forming system that scavenged sulfur from deeply buried sedimentary sequences or from felsic igneous rocks. However, they are not consistent with a purely magmatic origin or with an origin by bacterial reduction of seawater sulfate.

Sulfur-isotope fractionations between pyrite and chalcopyrite are -1.0 to +0.2 per mil in samples from the Dandy and Blacktail zones, and fractionations between pyrrhotite and chalcopyrite are about -0.4 per mil in samples from the Chicago, Brown Bear, and Blacktail zones. Such small fractionations indicate sulfur-isotope mineral equilibration at temperatures higher than normal for seafloor hydrothermal deposits, either volcanogenic or sedimentary exhalative. This higher temperature equilibration lends support to the hypothesis that much of the stratabound ore formed by epigenetic mineralization of favorable host strata rather than by exhalative deposition at the seafloor surface.

\section{History of Mineralization, Deformation, and Metamorphism}

The present assemblage of stratabound and discordant ore deposits of the Blackbird mine area may have resulted from metamorphic-hydrothermal effects superimposed on submarine-volcanic-related chemical-sedimentary layers that were geochemically enriched in the constituents of ore and gangue minerals that are concentrated in and around layers of biotite rock and silica rock. We continue to gather information about the structural geology and geochronology of the Blackbird deposits and their host rocks in an effort to understand their history of mineralization, deformation, and metamorphism.

\section{Acknowledgments}

Greg Hahn donated his library of published and unpublished reports on Blackbird and the Idaho cobalt belt. Gordon Hughes provided polished ore slabs from each of the major Blackbird ore zones and notable prospects, and Mike Zientek donated samples from the Dandy zone. Bill Scales and George King (Formation Capital Corporation) made drill core available for inspection, discussion, and sampling. Dan Meyers (Noranda Inc.) gave permission for underground tours, led by Bruce Hull and Brett Riggan. Tom Nash, John Slack, Mike O'Neill, Jerry Zieg, Don Winston, Paul Link, Reed Lewis, and Virginia Gillerman provided information and insights based on their knowledge of the regional stratigraphy, structural geology, and mineral deposits of the Belt Basin. John Wallis digitized figure 2, and James Evans and Douglas Causey provided helpful technical reviews.

\section{References Cited}

Anderson, A.L., 1947, Cobalt mineralization in the Blackbird district, Lemhi County, Idaho: Economic Geology, v. 42, p. 22-46.

Ballentine, C.J., Burgess, R., and Marty, B., 2000, Tracing fluid origin, transport and interaction in the crust, in Porcelli, D., Ballentine, C.J., Wieler, R., eds., Noble gases in geochemistry and cosmochemistry: Reviews in Mineralogy and Geochemistry, vol. 48, p. 539-614.

Barker, A.J., 1998, Introduction to metamorphic textures and microstructures: Cheltenham, U.K., Stanley Thornes (Publishers), Ltd., 263 p.

Bending, J.S., and Scales, W.G., 2001, New production in the Idaho Cobalt belt: a unique metallogenic province: Transactions of the Institution of Mining and Metallurgy (Section B), Applied Earth Science, v. 110, p. B81-B87.

Bennett, E.H., 1977, Reconnaissance geology and geochemistry of the Blackbird Mountain-Panther Creek region, Lemhi County, Idaho: Idaho Bureau of Mines and Geology pamphlet, $167 \mathrm{p}$.

Connor, J.J., Evans, K.V., Briggs, P.H., Crock, J.G., Hopkins, R.T., Kennedy, K.R., O’Leary, R.M., Roushey, B.H., Slaughter, K.E., and Welsch, E.P., 1991, Chemical analyses of rock samples collected in east-central Idaho during a study of mineralization in the northern Lemhi Range, Lemhi County, Idaho: U.S. Geological Survey Open-File Report 90-0655, $48 \mathrm{p}$.

Doughty, P.T., and Chamberlain, K.R., 1996, Salmon River arch revisited-New evidence for 1370 Ma rifting near the end of deposition in the Middle Proterozoic Belt Basin: Canadian Journal of Earth Sciences, v. 33, no. 7, p. 1037-1052. 
Earhart, R.L., 1986, Descriptive model of Blackbird Co-Cu, in Cox, D.P. and Singer, D.A., eds., Mineral deposit models: U.S. Geological Survey Bulletin 1693, p. 142.

Eiseman, H.H., 1988, Ore geology of the Sunshine cobalt deposit, Blackbird mining district, Idaho: Golden, Colorado School of Mines, M.S. thesis, 191 p.

Evans, K.V., and Green, G.N., 2003, Geologic map of the Salmon National Forest and vicinity, east-central Idaho: U.S. Geological Survey Geologic Investigations Series Map I-2765, 2 sheets, scale 1:100,000, pamphlet, 19 p.

Evans, K.V., Nash, J.T., Miller, W.R., Kleinkopf, M.D., and Campbell, D.L., 1995, Blackbird Co-Cu deposits, in du Bray, E.A., ed., Preliminary compilation of descriptive geoenvironmental mineral deposit models: U.S. Geological Survey Open-File Report 95-831, p. 145-151.

Evans, K.V., and Zartman, R.E., 1990, U-Th-Pb and Rb-Sr geochronology of middle Proterozoic granite and augen gneiss, Salmon River Mountains, east-central Idaho: Geological Society of America Bulletin, v. 102, p. 63-73.

Formation Capital Corporation, 2007, Grade and tonnage of the Ram deposit: Formation Capital website ( $w w w$.formcap. com). Accessed Feb 26, 2007.

Hughes, G.H., 1983, Basinal setting of the Idaho cobalt belt, Blackbird mining district, Lemhi County, Idaho, in Ranta, D.E., Kamilli, R.J., and Pansze, A.G., eds., The Genesis of Rocky Mountain Ore Deposits_Changes with Time and Tectonics: Denver Region Exploration Geologists Symposium, Nov. 4-5, 1982, Proceedings, p. 21-27.

Hughes, G.H., 1990, The Blackbird mining district, Lemhi County, Idaho, in Moye, F.J., ed., Geology and ore deposits of the trans-Challis fault system/Great Falls tectonic zone: Tobacco Root Geological Society Field Conference, 15th, Guidebook, p. 5-29.

Link, P.K., Fanning, M.C., Lund, K.I., and Aleinikoff, J.N., 2007, Detrital zircon populations and provenance of Mesoproterozoic strata of east-central Idaho, U.S.A.-Correlation with Belt Supergroup of southwest Montana, in Proterozoic geology of western North America and Siberia: SEPM Special Publication 86, p. 101-128.

Lund, K.J., and Tysdal, R.G., 2007, Stratigraphic and structural setting of sediment-hosted Blackbird gold-cobaltcopper deposits, east-central Idaho, U.S.A., in Proterozoic geology of western North America and Siberia: SEPM Special Publication 86, p. 129-147.

Modreski, P.J., 1985, Stratabound cobalt-copper deposits in the Middle Proterozoic Yellowjacket Formation in and near the Challis quadrangle, in McIntyre, D.H., ed., Symposium on the geology and mineral deposits of the Challis $1^{\circ} \times 2^{\circ}$ quadrangle, Idaho: U.S. Geological Survey Bulletin 1658, p. 203-222.

Nash, J.T., 1989a, Geology and geochemistry of synsedimentary cobaltiferous-pyrite deposits, Iron Creek, Lemhi County, Idaho: U.S. Geological Survey Bulletin 1882, 33 p.

Nash, J.T., 1989b, Chlorine-rich biotites from the Blackbird mining district, Lemhi County, Idaho-Evidence for a saline hydrothermal brine: U.S. Geological Survey OpenFile Report 89-445, 25 p.

Nash, J.T., and Connor, J.J., 1993, Iron and chlorine as guides to stratiform $\mathrm{Cu}-\mathrm{Co}-\mathrm{Au}$ deposits, Idaho cobalt belt: Mineralium Deposita, v. 28, p. 99-106.

Nash, J.T., and Hahn, G.A., 1989, Stratabound Co-Cu deposits and mafic volcaniclastic rocks in the Blackbird mining district, Lemhi County, Idaho, in Boyle, R.W., Brown, A.C., Jefferson, C.W., Jowett, E.C., and Kirkham, R.V., eds., Sediment-hosted stratiform copper deposits: Geological Association of Canada Special Paper 36, p. 339-356.

Nold, J.L., 1990, The Idaho cobalt belt, northwestern United States-A metamorphosed Proterozoic exhalative ore district: Mineralium Deposita, v. 25, p. 163-168.

Roberts, W.A., 1953, Metamorphic differentiates in the Blackbird mining district, Lemhi County, Idaho: Economic Geology, v. 48, p. 447-456.

Slack, J.F., 2006, High REE and Y concentrations in Co$\mathrm{Cu}-\mathrm{Au}$ ores of the Blackbird district, Idaho: Economic Geology, v. 101, p. 275-280.

Strauss, Harald, and Schrieber, Jurgen, 1990, A sulfur isotope study of pyrite genesis - The Mid-Proterozoic Newland Formation, Belt Supergroup, Montana: Geochimica et Cosmochimica Acta, v. 54, p. 197-204.

Vhay, J.S., 1948, Cobalt-copper deposits in the Blackbird district, Lemhi County, Idaho: U.S. Geological Survey Strategic Minerals Investigation Preliminary Report 3-219, 26 p., 3 plates. 


\section{Geochemical and Mineralogical Studies of Sulfide and Iron Oxide Deposits in the Idaho Cobalt Belt}

By John F. Slack

Chapter C of

Metallogeny of Mesoproterozoic Sedimentary Rocks in Idaho and Montana-Studies by the Mineral Resources Program, U.S. Geological Survey, 2004-2007

Edited by J. Michael O'Neill

Open-File Report 2007-1280-C 


\section{Contents}

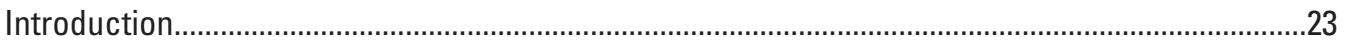

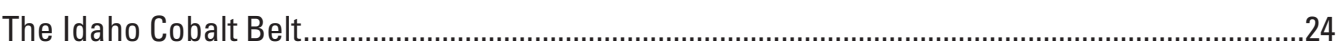

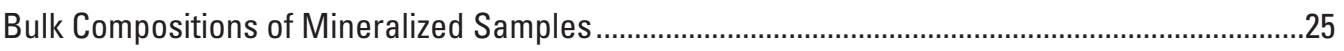

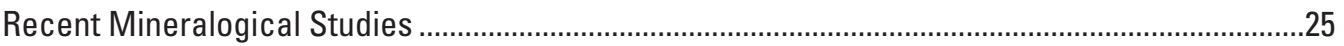

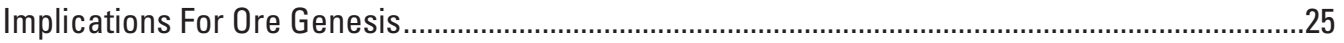

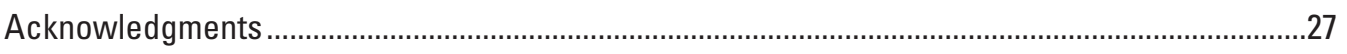



\section{Figure}

1. Simplified geologic map of the Idaho cobalt belt showing locations of major sulfide and iron oxide deposits. 


\title{
Geochemical and Mineralogical Studies of Sulfide and Iron Oxide Deposits in the Idaho Cobalt Belt
}

\author{
By John F. Slack
}

\section{Introduction}

This chapter reports progress on geochemical and mineralogical studies of sulfide deposits in the Idaho cobalt belt (fig. 1) and continues the reconnaissance work presented in Slack (2006). Emphasis is on samples of stratabound Co$\mathrm{Cu}-\mathrm{Au}$ ore and mineralized rock from deposits in the Blackbird mining district, but data for other deposit types in the belt are also discussed: stratabound zones of pyrite-rich magnetite and massive magnetite in the Iron Creek area, at the southeast end of the belt, and a specular hematite vein from the McKim Creek prospect in the Lemhi Range southeast of the cobalt belt. Important microtextural and paragenetic relationships in the $\mathrm{Co}-\mathrm{Cu}-\mathrm{Au}$ samples that have a bearing on ore genesis are described, and possible ore deposit models for these Co$\mathrm{Cu}-\mathrm{Au}$ ores are evaluated.
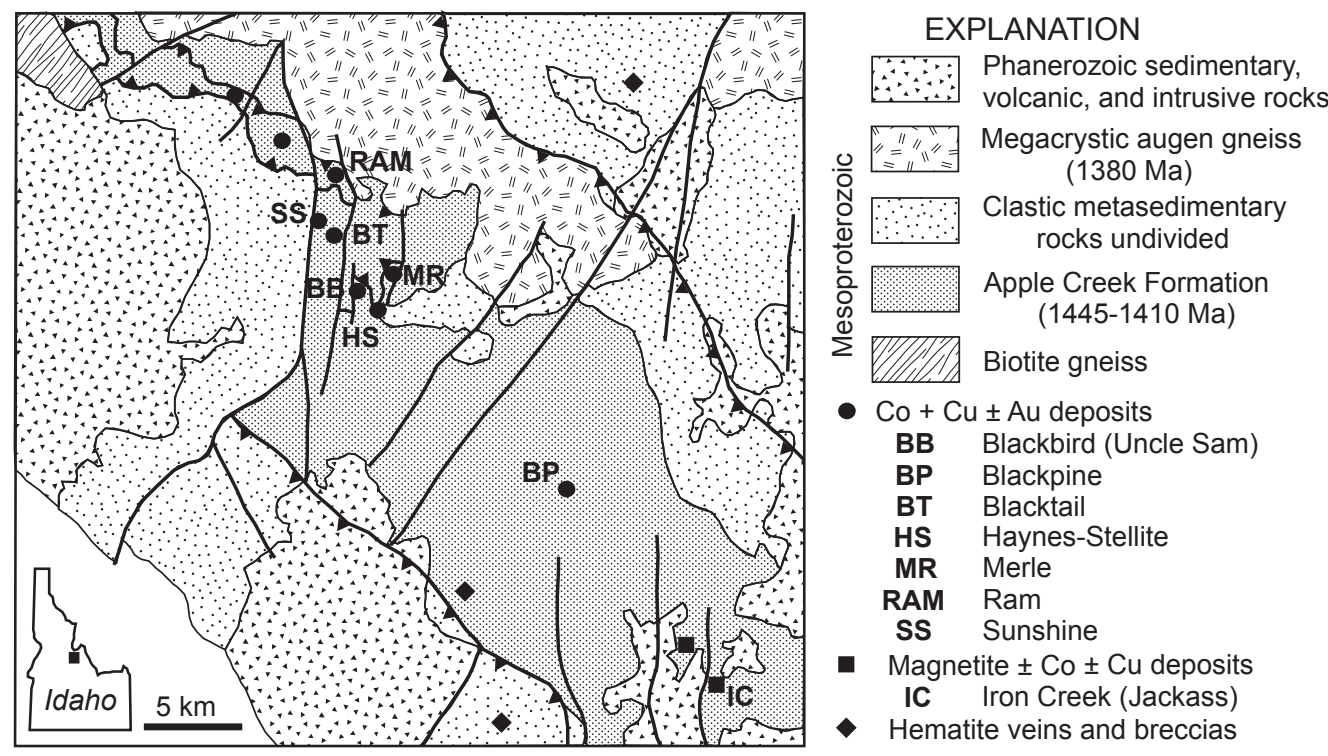

Figure 1. Simplified geologic map of the Idaho cobalt belt showing the locations of major stratabound sulfide deposits and stratabound and discordant iron oxide deposits (modified from Slack, 2006). Geology from Tysdal and others (2003) and Lund and Tysdal (2007). Ages of the augen gneiss body and the Apple Creek Formation are from Lund and others (2004) and Link and others (2007), respectively. Locations of sulfide deposits are from Reed and Herdlick (1947), Nash and Hahn (1989), and Bookstrom and others (this volume); iron oxide deposits are from Modreski (1985) and Nash (1989). Other sulfide deposits not shown here but mentioned in the text (for example, Dandy, Brown Bear) are located between the Merle and Blacktail deposits (see Bookstrom and others, this volume). Note that the Haynes-Stellite deposit is a discordant, sulfide-bearing tourmalinized breccia pipe. The garnet isograd (after Nash and Hahn, 1989), shown by the open hexagon symbol, in this part of the district is coincident with the southern trace of the Iron Creek thrust fault of Lund and Tysdal (2007). EC, Elkhorn Creek Cu-Co anomaly (see Bookstrom and others, this volume); ICS, Iron Creek subplate. 


\section{The Idaho Cobalt Belt}

Stratabound mineral deposits of the Idaho cobalt belt of central Idaho (fig. 1) are strategically important because they contain the largest cobalt resource known in the United States. Bookstrom and others (this volume) summarize the past mining history and production in the region and estimate the sizes and grades of unmined metal concentrations. The stratabound deposits comprise both sulfide and oxide accumulations. All of these deposits occur in the siliciclastic Apple Creek Formation, of Mesoproterozoic age, mostly within the banded siltite unit as described by Tysdal and others (2003) and Lund and Tysdal (2007). A megacrystic augen gneiss body having a U-Pb zircon age of $\sim 1380 \mathrm{Ma}$ (Lund and others, 2004) crops out to the north of the belt (fig. 1). The Mesoproterozoic rocks in the region are deformed by outcrop-scale folds and are cut by thrust faults of probable Cretaceous age; high-angle faults are mainly Tertiary (Lund and Tysdal, 2007). Older Proterozoic deformation in the cobalt belt cannot be ruled out, however, given the presence in wallrocks to the $\sim 1380$ Ma megacrystic augen gneiss of folds with axial-planar fabrics that are cut by this body (see Bookstrom and others, this volume) and of a Lu-Hf age of $1194 \pm 4$ Ma for the core of a garnet crystal from amphibolite in northern Idaho (Vervoort and others, 2005). Metamorphic grade in the study area ranges from lower greenschist in the southeast part of the cobalt belt, within the Iron Creek area, to middle or upper amphibolite in the northwest part, at and near the Salmon Canyon deposit. In the Blackbird district and vicinity, Vhay (1948) and Nash and Hahn (1989) recognized and mapped a garnet isograd, which Lund and Tysdal (2007) consider to be coincident with the southern trace of the Indian Creek thrust fault (fig. 1).

The stratabound sulfide deposits in the Blackbird district form stratiform to irregular lenses and subordinate veins within laminated siliceous rock and stratiform biotite-rich rock (Nash and Hahn, 1989; Bookstrom and others, this volume). The latter rock type, commonly termed "biotitite" by most previous workers, consists mainly of green biotite with minor chlorite, quartz, chloritoid, and Cl-rich scapolite in strata at middle greenschist grade; garnet and $\mathrm{Al}$-rich silicate minerals including possible cordierite and sillimanite are present in the biotitite beds at higher metamorphic grade (see Lund and Tysdal, 2007). The author has also tentatively identified andalusite in biotitite beds from the Ram deposit. The origin of the stratiform biotitites is uncertain; they have variously been interpreted as altered mafic alkaline tuffs, metamorphosed hydrothermal alteration zones, and metamorphosed exhalative chemical sediments (Nash and Hahn, 1989; Nash and Connor, 1993; Bookstrom and others, this volume).

Several nonstratabound sulfide deposits also occur in the district. One type is the discordant Dandy zone, consisting of massive pyrrhotite and marcasite with minor chalcopyrite and quartz, which Nash and Hahn (1989) suggested was a feeder to the adjacent stratiform Chicago and Idaho deposits. A second type occurs within tourmalinized breccia pipes that contain minor cobaltite and secondary Co minerals, such as at the Haynes-Stellite deposit (fig. 1; see Bookstrom and others, this volume).

Deformational features in the deposits include folds, faults, and shear zones. Folds are evident on a range of scales from meter-sized structures exposed in outcrops and underground mine faces to smaller structures seen in hand specimens and thin sections. In the Blacktail deposit, high-grade $\mathrm{Co}-\mathrm{Cu}$ ore zones are aligned with north-plunging folds (Vhay, 1948), providing evidence for a predeformational origin for at least some of the sulfide mineralization. On smaller scales, sulfide ore from the dump of the Sunshine deposit shows quartz and cobaltite layers that can be traced continuously around the nose of a 10-cm-amplitude fold, and drill core from the Ram deposit displays classic "durchbewegung" texture (for example, Vokes, 1969; Marshall and Gilligan, 1993) in which semimassive to massive cobaltite is infolded within schistose wallrock. Cobaltite has also been found in the cores of elongate, stretched garnets. In some parts of the district, apparent pretectonic features can be recognized, such as in the Chicago deposit where a 1- to 2-m-thick lens composed of massive chalcopyrite with minor pyrrhotite and cobaltite cuts bedding in the host siltite at a low angle (S.G. Peters, U.S. Geological Survey, oral commun., 2005). Possible soft-sediment deformational features are also reported to occur locally in some deposits (Bookstrom and others, this volume).

Stratabound magnetite-sulfide deposits in the Iron Creek area were studied by Nash (1989). The detailed geometry of these deposits is poorly known, owing to limited information from drill cores. However, at map scale the deposits appear to be broadly conformable with their metasedimentary host strata and hence are stratiform. Whether they are also bedded and stratiform is unclear. Biotite-rich rocks apparently are not associated with the magnetite-sulfide deposits in the Iron Creek area, in contrast to most of the deposits in the Blackbird district to the north.

The ore mineralogy of the sulfide deposits is dominated by cobaltite or chalcopyrite (or both) with generally minor pyrite, arsenopyrite, safflorite, pyrrhotite, and gold. Locally present in trace to minor amounts are native bismuth, bismuthinite, millerite, uraninite, and one or more unidentified Bi-Te phases (Anderson, 1947; Vhay, 1948; Bennett, 1977; Eiseman, 1988; Nash and Hahn, 1989). In a mineralogical study of the Sunshine deposit, Eiseman (1988) reported the presence of minor allanite, a mineral that contains major amounts of light rare-earth elements (LREE) $\left.\left[(\mathrm{Ca}, \mathrm{LREE}, \mathrm{Y})_{2}\left(\mathrm{Al}_{2} \mathrm{Fe}^{3+}\right)_{3} \mathrm{Si}_{3}\right)_{12}(\mathrm{OH})\right]$. Reconnaissance microbeam studies by Slack (2006), which used scanning electron microscope-energy dispersive spectrometry (SEM-EDS) on sulfide samples from the Sunshine and Merle deposits (fig. 1), discovered locally abundant monazite [(LREE,Y,Th) $\left.\mathrm{PO}_{4}\right]$ and xenotime, the latter mineral containing major amounts of heavy rare earth elements (HREE) - [(Y,HREE) $\left.\mathrm{PO}_{4}\right]$. These REErich minerals tend to occur preferentially in Co-rich samples, as a matrix to disseminated cobaltite or interstitial to massive cobaltite. Allanite is also abundant in deposits such as Brown Bear, where it constitutes $\sim 30$ vol percent of some samples 
together with cobaltite and lesser epidote, apatite, chalcopyrite, and quartz. More recent SEM-EDS work by the author has identified abundant gadolinite $\left[(\mathrm{Y}, \mathrm{Ce})_{2} \mathrm{Fe}^{2+} \mathrm{Be}_{2} \mathrm{Si}_{2} \mathrm{O}_{10}\right]$ in one sample from the Northfield deposit (fig. 1). Gangue minerals in the sulfide deposits comprise major quartz, and minor biotite, chlorite, muscovite, garnet, tourmaline, apatite, and siderite.

Stratabound pyrite-rich magnetite deposits in the Iron Creek area (fig. 1) consist mainly of magnetite and cobaltiferous pyrite with trace to minor amounts of chalcopyrite in a gangue composed dominantly of quartz (Nash, 1989).

\section{Bulk Compositions of Mineralized Samples}

Slack (2006) reported the results of a reconnaissance geochemical study of 15 samples of $\mathrm{Co}-\mathrm{Cu}-\mathrm{Au}$ ore and mineralized rock from the Blackbird district. This study was the first to use high-precision inductively coupled plasma-mass spectrometry (ICP-MS) on fused samples of sulfide-bearing rocks from the district. In addition to the known concentrations of $\mathrm{Co}, \mathrm{Cu}$, and $\mathrm{Au}$, Slack (2006) discovered in 11 sulfide-rich samples previously unrecognized high contents of REE and Y, which average 0.53 wt percent $\Sigma$ REE $+Y$ oxides; some samples also have relatively high concentrations of As (maximum 17.3 wt percent), Bi (maximum 2,953 parts per million (ppm)), and $\mathrm{Ni}$ (maximum 1,330 ppm). Since that study, 40 additional mineralized samples from the district have been analyzed by a combination of methods including ICP-MS, instrumental neutron activation analysis (INAA), fire assay-mass spectrometry, and inductively coupled plasma-optical emission spectrometry (ICP-OES). Data from these new analyses confirm the abundances of REE and $\mathrm{Y}$ in some $\mathrm{Co}-\mathrm{Cu}-\mathrm{Au}$ ores of the Blackbird district and indicate that several sulfide-rich samples have 2 to nearly 4 wt percent $\Sigma R E E+Y$ oxides. The new analyses show even higher Bi (maximum $9.2 \mathrm{wt}$ percent) and $\mathrm{Ni}$ (maximum 6,780 ppm) concentrations; $\mathrm{Sb}$ (maximum $429 \mathrm{ppm}$ ), Te (maximum $250 \mathrm{ppm}$ ), and $\mathrm{U}$ (maximum 124 $\mathrm{ppm}$ ) contents are elevated in a few samples. Significantly, in this larger dataset, selected samples also have concentrations of Sn (133 ppm) and W (142 ppm) that are anomalously high compared with those for most stratabound sulfide ores. One sulfide-rich rock from the Northfield deposit (fig. 1), which contains 4.2 wt percent $\mathrm{Co}, 3.7$ wt percent $\mathrm{Cu}$, and $0.9 \mathrm{ppm}$ $\mathrm{Au}$, is significant in also having $1,180 \mathrm{ppm} \mathrm{Be}$. Chalcopyriterich ore from the Salmon Canyon copper deposit (one sample) has 2.2 wt percent $\mathrm{Co}, 5.9$ wt percent $\mathrm{Cu}, 11.3$ wt percent As, $4.8 \mathrm{ppm} \mathrm{Au}, 2,110 \mathrm{ppm} \mathrm{Bi}, 2,220 \mathrm{ppm} \mathrm{Ni}, 78 \mathrm{ppm} \mathrm{Sb}$, and $516 \mathrm{ppm}$ Y. Analysis of a subset of 21 sulfide-rich samples by fire assay-mass spectrometry indicates very low concentrations of $\mathrm{Pt}$ (maximum $1.0 \mathrm{ppb}$ ) and $\mathrm{Pd}$ (maximum $0.7 \mathrm{ppb}$ ). In the entire dataset for the Blackbird district $(n=55), \mathrm{Zn}$ is slightly high in a few samples (maximum $929 \mathrm{ppm}$ ), but $\mathrm{Pb}$ and Mo are uniformly low (maximum 144 ppm and 25 ppm, respectively).
Samples of stratabound pyrite-rich magnetite rock from the Iron Creek area (fig. 1) were also analyzed for bulk compositions. Results for three drill cores from the No-Name zone show elevated contents of several metals: the most pyritic sample, containing $\sim 50$ vol percent euhedral pyrite, also contains 1.3 wt percent $\mathrm{Co}, 255 \mathrm{ppm} \mathrm{Cu}, 74 \mathrm{ppb} \mathrm{Au}, 372 \mathrm{ppm}$ As, $1,010 \mathrm{ppm} \mathrm{Bi}$, and $310 \mathrm{ppm} \mathrm{Ni}$; the other two samples have lower $\mathrm{Co}$ (maximum 6,860 ppm) and very low $\mathrm{Cu}$ (maximum $46 \mathrm{ppm}$ ) and $\mathrm{Au}$ (maximum $58 \mathrm{ppb}$ ) but elevated concentrations of other metals including as much as $1,290 \mathrm{ppm} \mathrm{Bi}$, $156 \mathrm{ppm} \mathrm{Te}$, and $43 \mathrm{ppm} \mathrm{W}$. Approximately $2 \mathrm{~km}$ south of the center of the No-Name zone, one roadside outcrop in the Jackass zone that consists of massive magnetite with minor disseminated sulfides contains 3.2 wt percent Co, 2,180 ppm $\mathrm{Cu}, 896 \mathrm{ppb} \mathrm{Au}, 4.3$ wt percent As, 67 ppm Bi, 661 ppm Ni, and $420 \mathrm{ppm}$ Y. A vein of massive specular hematite from the McKim Creek prospect, in the Lemhi Range southeast of the cobalt belt (see Bookstrom and others, this volume), contains 355 ppm Co, 51 ppm Cu, 20 ppb Au, 2,940 ppm As, and 142 ppm W.

\section{Recent Mineralogical Studies}

Sulfide-rich samples from the Idaho cobalt belt have been studied using a petrographic microscope and SEM-EDS analysis. Recently acquired SEM-EDS data confirm and expand the observations reported by Slack (2006), particularly with respect to the mineralogical residence of REE and $\mathrm{Y}$ within allanite, monazite, and xenotime. Important discoveries resulting from this new work are as follows: (1) large amounts of allanite ( 20-30 vol percent) occur locally, generally with intergrown epidote and minor apatite, such as in the Brown Bear deposit; (2) allanite is volumetrically minor in the Sunshine deposit and may be rare in the Ram deposit; (3) monazite appears to be abundant only in the Sunshine and Ram deposits; (4) xenotime occurs rarely as small inclusions in cobaltite grains, but monazite inclusions in cobaltite have not been found; (5) allanite in the Sunshine, Ram, and Merle samples is commonly replaced by monazite and locally by xenotime; and (6) gadolinite is a volumetrically major mineral in one $\mathrm{Co}$ - and $\mathrm{Cu}$-rich sample from the Northfield deposit, forming compositionally zoned grains both in the matrix to cobaltite and as inclusions within cobaltite.

\section{Implications For Ore Genesis}

Diverse genetic models have been proposed for the Co$\mathrm{Cu}-\mathrm{Au}$ deposits of the Blackbird district including formation from volcanogenic massive sulfide (VMS), sedimentaryexhalative (SEDEX), stratiform copper, and iron oxidecopper-gold (IOCG) mineralizing systems (Modreski, 1985; Nash and Hahn, 1989, Nold, 1990; Bending and Scales, 2001; Slack, 2006). A carbonatite-related origin is also possible, 
given the high REE contents of some samples in the district, but this model is considered unlikely because REE-rich carbonatite deposits lack the $\mathrm{Co}-\mathrm{Cu}-\mathrm{Au}-\mathrm{Bi}-\mathrm{Ni}$ metal assemblage that characterizes the Blackbird sulfide samples. In the author's opinion, the weight of the evidence obtained to date argues for an IOCG genetic model (see Williams and others, 2005; Johnson and Barton, in press). This model encompasses several types of mineralizing systems but mainly involves magmatic-hydrothermal fluids.

The age of sulfide mineralization in the cobalt belt is enigmatic. Since the study by Bennett (1977), who proposed an epigenetic origin related to the augen gneiss body (then believed to be part of the Idaho batholith), most workers have considered the deposits to be broadly coeval with their Mesoproterozoic host rocks, having formed by either VMS or SEDEX processes. However, recent sensitive high-resolution ion microprobe (SHRIMP) U-Pb dating of 10 monazite grains from the Sunshine deposit by John Aleinikoff (Slack and others, 2006) yielded a ${ }^{206} \mathrm{~Pb} /{ }^{238} \mathrm{U}$ age of $90.8 \pm 1.2 \mathrm{Ma}$. This Late Cretaceous age is close to a $\mathrm{Lu}-\mathrm{Hf}$ age of $89.6 \pm 2.6 \mathrm{Ma}$ for metamorphic garnet in northern Idaho (Vervoort and others, 2005). Such similarity in ages raises the possibility that the monazite in the Sunshine deposit - and by implication the associated $\mathrm{Co}-\mathrm{Cu}-\mathrm{Au}$ ores - also formed during a Late Cretaceous metamorphic event. This hypothesis is undercut, though, by textural evidence showing that in the Sunshine and Ram deposits, cobaltite grains locally occur in the cores of garnet crystals (Eiseman, 1988; this study). A Cretaceous origin for the sulfide mineralization in the district cannot be ruled out, for example by multiple hydrothermal and metamorphic processes in which the $\mathrm{Co}-\mathrm{Cu}$-Au-REE-Y deposits formed early and the garnet and monazite grains formed late, all during the Late Cretaceous. However, in the author's opinion, the presence of Cretaceous monazite in the Blackbird deposits is better explained by its formation during regional metamorphism from pre-Cretaceous allanite and apatite. Recent SEM studies by the author show that monazite replaces allanite in several samples from the Sunshine, Ram, and Merle deposits, and that allanite + apatite is a major assemblage in a few other deposits of the district such as Brown Bear and Merle. In pelitic schists metamorphosed under Barrovian-type high-P conditions, trace amounts of monazite form at the staurolite isograd by the breakdown of REE- and P-bearing garnet + muscovite + chlorite (Kohn and Malloy, 2004). However, this process does not explain the abundance of monazite (and LREE) in some of the Blackbird district samples. More relevant is the work of Wing and others (2003), who proposed that under Buchans-type low-P conditions at the andalusite isograd, allanite + apatite + muscovite + andalusite + quartz react to form monazite + biotite + Ca-plagioclase + water. This latter reaction does not appear to be completely applicable to the Blackbird district, because plagioclase has not been found together with monazite in the Sunshine and Ram deposits, even in sparse amounts. Other products of the breakdown of allanite + apatite may have formed with monazite, such as ankerite + siderite + muscovite; these and similar assemblages will be evaluated during the remainder of this study. Regardless of the metamorphic reaction or reactions involved, it seems likely that allanite and apatite, as well as xenotime, existed in the Blackbird deposits prior to Cretaceous metamorphism. This interpretation is supported by the apparent restriction of abundant monazite to the Sunshine and Ram deposits, which occur above the garnet isograd. It is also consistent with evidence for REE mineralization in the Mesoproterozoic in the Belt-Purcell Basin to the east and north: in the Lemhi Pass district along the Idaho-Montana border, where large Th-REE-Cu-Fe veins contain molybdenite with a Re-Os age of $\sim 1100 \mathrm{Ma}$ (Gillerman and others, 2002), and in the Sullivan deposit, southeastern British Columbia, where small Ti-Nb-REE veins contain polycrase with a SHRIMP ${ }^{207} \mathrm{~Pb} /{ }^{206} \mathrm{~Pb}$ age of $1415 \pm 5 \mathrm{Ma}$ (Slack and others, 2004).

Geochemical data on the mineral deposits of the cobalt belt provide evidence that they formed by a common process. As outlined above, the $\mathrm{Co}-\mathrm{Cu}-\mathrm{Au}$ sulfide deposits in the Blackbird district have a strong accessory metal signature involving, in most samples, high $\mathrm{Bi}, \mathrm{Ni}$, REE, and Y. Abundance of the Y- and Be-rich mineral gadolinite in one sample from the Northfield deposit supports a link between this mineralization and formation of the other Y-rich minerals in the district. The presence of gadolinite grains within cobaltite crystals at Northfield further suggests - but does not provethat the Be concentration there was not introduced during or after Cretaceous metamorphism, but instead formed together with cobaltite during the Mesoproterozoic. Relatively high contents of $\mathrm{Bi}, \mathrm{Ni}$, and $\mathrm{Y}$ in the stratabound pyritic magnetite deposits of the Iron Creek area and elevated Co and As in the McKim Creek hematite vein provide a possible link to the Blackbird Co-Cu-Au deposits, and these data are consistent with a model in which all of these diverse deposits formed by similar mineralizing processes.

The source of the mineralizing fluids is unclear. High REE and $\mathrm{Y}$ concentrations in many of the sulfide deposits suggests a magmatic source, which is also supported by the presence of elevated Sn and W in several of the Blackbird deposits and by high Be in the Northfield deposit. However, high Sn, $\mathrm{W}$, and Be concentrations are not unique to magmatically derived mineral deposits (for example, Slack and others, 2000; Barton and Young, 2002). Nevertheless, recent He isotope analysis of quartz gangue from the Sunshine deposit provides strong evidence for a magmatic component in the hydrothermal fluids. Bookstrom and others (this volume) report a large proportion of mantle-derived ${ }^{3} \mathrm{He}$ in this quartz, which may reflect the involvement of mantle-derived magmas such as carbonatites or granites. Although small Mesoproterozoic(?) carbonatite dikes and veins exist tens of kilometers or more to the north and east of the Blackbird district (for example, Anderson, 1960; Gibson and Wood, 1997), for the metallogenic reasons outlined above they are unlikely candidates for the magmatic fluid source. The large $1380 \mathrm{Ma}$ augen gneiss body along the northern border of the district is a more plausible source for the hydrothermal fluids, although the original granitic intrusion that now makes up this gneiss was emplaced 30-70 m.y. after deposition of the Apple Creek Formation. 
A unified genetic model for the mineral deposits in the Idaho cobalt belt is still undefined and will require additional studies. Strictly exhalative to synsedimentary origins are problematic, because of the absence of key features that are characteristic of such deposits, such as laterally extensive stratiform sulfides and finely laminated ore minerals. However, laminated textures, if they existed, could have been destroyed by the postore deformation and metamorphism in the district. A late diagenetic origin is also possible but is difficult to evaluate for similar reasons. In the author's current view, the most likely genetic model involves Mesoproterozoic replacement of permeable sediments or chemically favorable host strata (or both), either during late diagenesis or later following lithification of the sediment.

One mineralizing process that deserves consideration is epigenetic formation of the $\mathrm{Co}-\mathrm{Cu}-\mathrm{Au}$ ores, by which magmatically derived fluids selectively replaced biotitite beds (or their protoliths). Replacement of biotitite may have been promoted by the chemical reactivity of the Fe-rich biotitites, which could have reduced and precipitated the constituents of oxidized hydrothermal fluids. In an alternative model, the biotitites might have formed during $\mathrm{Co}-\mathrm{Cu}-\mathrm{Au}$ mineralization by the hydrothermal alteration of siliciclastic sedimentary wall rocks. Better constraints on the origin of the biotitite beds are needed before these hypotheses can be evaluated.

\section{Acknowledgments}

I thank Greg Hahn, formerly of Noranda Inc., for introducing me to the Idaho cobalt belt nearly 30 years ago, and Art Bookstrom, Tom Nash, Karen Lund, and Karl Evans of the U.S. Geological Survey for sharing their knowledge of the local geology and mineral deposits. I am indebted to Bill Scales and George King of Formation Capital Corporation for providing access to drill cores for sampling, and to Gordon Hughes, formerly of Noranda Inc., and Steve Peters of the U.S. Geological Survey, who supplied many of the rocks analyzed in this study; Art Bookstrom of the U.S. Geological Survey and Virginia Gillerman of the Idaho Geological Survey also donated samples for analysis. Harvey Belkin of the U.S. Geological Survey provided electron microprobe data that were critical for identifying gadolinite in the Northfield deposit. The manuscript was improved by the reviews of Art Bookstrom and Craig Johnson of the U.S. Geological Survey.

\section{References Cited}

Anderson, A.L., 1947, Cobalt mineralization in the Blackbird district, Lemhi County, Idaho: Economic Geology, v. 42, p. 22-46.

Anderson, A.L., 1960, Genetic aspects of the monazite and columbium-bearing rutile deposits in northern Lemhi County, Idaho: Economic Geology, v. 55, p. 1179-1201.
Barton, M.D., and Young, S., 2002, Non-pegmatitic deposits of beryllium-Mineralogy, geology, phase equilibria and origin: Reviews in Mineralogy and Geochemistry, v. 50, p. 591-691.

Bending, J.S., and Scales, W.G., 2001, New production in the Idaho cobalt belt-A unique metallogenic province: Transactions of the Institution of Mining and Metallurgy, v. 110, sec. B, p. B81-B87.

Bennett, E.H., 1977, Reconnaissance geology and geochemistry of the Blackbird Mountain-Panther Creek region, Lemhi County, Idaho: Idaho Bureau of Mines and Geology Pamphlet 167, 108 p.

Eiseman, H.H., 1988, Ore geology of the Sunshine cobalt deposit, Blackbird mining district, Idaho: Golden, Colorado School of Mines, M.S. thesis, 191 p.

Gibson, P.E., and Wood, S.A., 1997, Mineralogy, geochemistry and mobility of the REE and thorium at Lemhi Pass, Idaho [abs.]: Geological Society of America Abstracts with Programs, v. 29, no. 6, p. 50.

Gillerman, V.S., Jercinovic, M.J., and Stein, H.J., 2002, $\mathrm{U}-\mathrm{Pb}$ and $\mathrm{Re}-\mathrm{Os}$ geochronology suggests a multistage Precambrian-Mesozoic history for thorium and copper mineralization, Lemhi Pass, Idaho [abs.]: Geological Society of America Abstracts with Programs, v. 34, no. 6, p. 337.

Johnson, D.A., and Barton, M.D., in press, Iron-oxide $\pm \mathrm{Cu}-$ Au-REE deposits and their by-products, in Orris, G.J., and Haxel, G.B., eds., Rare earth element resources-A basis for high technology: University of Arizona and U.S. Geological Survey Center for Mineral Resources, Monographs in Mineral Resource Science, v. 3.

Kohn, M.J., and Malloy, M.A., 2004, Formation of monazite via prograde metamorphic reactions among common silicates-Implications for age determinations: Geochimica et Cosmochimica Acta, v. 68, p. 101-113.

Link, P.K., Fanning, C.M., Lund, K.I., and Aleinikoff, J.N., 2007, Detrital zircon populations and provenance of Mesoproterozoic strata of east-central Idaho, U.S.A.: Correlation with Belt Supergroup of southwest Montana, in Link, P.K., and Lewis, R.S., eds., Proterozoic geology of western North America and Siberia: Society of Economic Paleontologists and Mineralogists Special Publication 86, p. 101-128.

Lund, K.I., Aleinikoff, J.N., Evans, K.V., and Kunk, M.J., 2004, Proterozoic basins and orogenic belts of central Idaho [abs.]: Geological Society of America Abstracts with Programs, v. 36, no. 5, p. 271.

Lund, K.I., and Tysdal, R.G., 2007, Stratigraphic and structural setting of sediment-hosted Blackbird gold-cobaltcopper deposits, east-central Idaho, U.S.A., in Link, P.K., and Lewis, R.S., eds., Proterozoic geology of western North America and Siberia: Society of Economic Paleontologists and Mineralogists Special Publication 86, p. 129-147. 
Marshall, Brian, and Gilligan, L.B., 1993, Remobilization, syn-tectonic processes and massive sulphide deposits: Ore Geology Reviews, v. 8, p. 39-64.

Modreski, P.J., 1985, Stratabound cobalt-copper deposits in the Middle Proterozoic Yellowjacket Formation in and near the Challis quadrangle: U.S. Geological Survey Bulletin 1658, p. 203-221.

Nash, J.T., 1989, Geology and geochemistry of synsedimentary cobaltiferous-pyrite deposits, Iron Creek, Lemhi County, Idaho: U.S. Geological Survey Bulletin 1882, 33 p.

Nash, J.T., and Connor, J.J., 1993, Iron and chlorine as guides to stratiform $\mathrm{Co}-\mathrm{Cu}-\mathrm{Au}$ deposits, Idaho cobalt belt, USA: Mineralium Deposita, v. 28, p. 99-106.

Nash, J.T., and Hahn, G.A., 1989, Stratabound Co-Cu deposits and mafic volcaniclastic rocks in the Blackbird mining district, Lemhi County, Idaho, in Boyle, R.W., Brown, A.C., Jefferson, C.W., Jowett, E.C., and Kirkham, R.V., eds., Sediment-hosted stratiform copper deposits: Geological Association of Canada Special Paper 36, p. 339-356.

Nold, J.L., 1990, The Idaho cobalt belt, northwestern United States-A metamorphosed Proterozoic exhalative ore district: Mineralium Deposita, v. 25, p. 163-168.

Reed, G.C., and Herdlick, J.A., 1947, Blackbird cobalt deposits, Lemhi County, Idaho: U.S. Bureau of Mines Report of Investigations 4012, $37 \mathrm{p}$.

Slack, J.F., 2006, High REE and Y concentrations in Co$\mathrm{Cu}-\mathrm{Au}$ ores of the Blackbird district, Idaho: Economic Geology, v. 101, p. 275-280.

Slack, J.F., Aleinikoff, J.N., Belkin, H.E., and Ransom, P., 2004, Mesoproterozoic polycrase-titanite veins in the Sullivan $\mathrm{Pb}-\mathrm{Zn}$-Ag deposit, southeastern British ColumbiaMineral chemistry, SHRIMP geochronology, and metallogenic significance [abs.]: Geological Society of America Abstracts with Programs, v. 36, no. 5, p. 445.

Slack, J.F., Aleinikoff, J.N., and Fanning, C.M., 2006, SHRIMP U-Pb geochronology of hydrothermal monazite in $\mathrm{Co}-\mathrm{Cu}-\mathrm{Au}$ ores of the Blackbird district, Idaho [abs.]:
Geological Society of America Abstracts with Programs, v. 38 , no. 7 , p. 372 .

Slack, J.F., Meier, A.L., Malcolm, M.J., Fey, D.L., Doughten, M.W., and Wandless, G.A., 2000, Trace element and rare-earth element geochemistry of bedded and massive sulphides from the Sullivan $\mathrm{Pb}-\mathrm{Zn}$-Ag deposit, British Columbia-A reconnaissance, in Lydon, J.W., Höy, T., Slack, J.F., and Knapp, M.E., eds., The geological environment of the Sullivan deposit, British Columbia: Geological Association of Canada Mineral Deposits Division Special Publication 1, p. 720-735.

Tysdal, R.G., Lund, K.I., and Evans, K.V., 2003, Geologic map of the western part of the Salmon National Forest: U.S. Geological Survey Geologic Investigations Series Map I-2765, scale 1:100,000 [http://pubs.usgs.gov/imap/i-2765/]

Vervoort, J.D., McClelland, W.C., Oldow, J.S., Watkinson, A.J., and Sha, G.S., 2005, Grenville-age metamorphism on the western margin of Laurentia, northern Idaho: Evidence from Lu-Hf garnet geochronology [abs.]: Geological Society of America Abstracts with Programs, v. 37, no. 7, p. 89.

Vhay, J.S., 1948, Cobalt-copper deposits in the Blackbird district, Lemhi County, Idaho: U.S. Geological Survey Strategic Minerals Investigation Preliminary Report 3-219, $26 \mathrm{p}$.

Vokes, F.M., 1969, A review of the metamorphism of sulphide deposits: Earth-Science Reviews, v. 5, p. 99-143.

Williams, P.J., Barton, M.D., Johnson, D.A., Fontboté, L., De Haller, A., Mark, G., Oliver, N.H.S., and Marschik, R., 2005, Iron oxide copper-gold deposits-Geology, space-time distribution, and possible modes of origin, in Hedenquist, J.W., Thompson, J.F.H., Goldfarb, R.J., and Richards, J.P., eds., Economic Geology 100th Anniversary Volume: Littleton, Colorado, Society of Economic Geologists, p. 371-405.

Wing, B.A., Ferry, J.M., and Harrison, T.M., 2003, Prograde destruction and formation of monazite and allanite during contact and regional metamorphism of pelites-Petrology and geochronology: Contributions to Mineralogy and Petrology, v. 145, p. 228-250.
Published in the Central Region, Denver, Colo.

Manuscript approved for publication September 5, 2007

Graphics by author

Photocomposition by Mari Kauffmann (Contractor, ATA Services)

Edited by Mary-Margaret Coates (Contractor, ATA Services) 